\title{
Cambio de perspectiva. El adentro y el afuera*
}

\author{
François Dagognet \\ Traducción del francés al español de Luis Alfonso Paláu-Castaño \\ Universidad Nacional de Colombia, Medellín, Colombia \\ lapalau@gmail.com
}

A Robert Damien, colega y amigo,

profesor de filosofía en la Universidad de Besançon

\section{Preámbulo}

Continuemos nuestros análisis. Con frecuencia -e incluso desde el comienzo- le hemos reprochado a la filosofía no haberse preocupado lo suficiente por la exterioridad (desacreditada para siempre) y por los objetos, a veces incluso ignorarlos para encerrarse mejor en la sola subjetividad (por esto la egología, el hortus conclusus). Carente de lo que la habría animado e incluso armado -el tener en cuenta nuestro entorno y a quien lo ocupa- la filosofía se repliega sobre sí misma, cree autonomizarse mientras se echa a perder. Nos atrevemos a preguntar, con el fin de poner en aprietos al filósofo hipotético que imaginamos y que sin duda caricaturizamos, sobre qué o a partir de qué eleva su reflexión.

Es verdad que él posee una respuesta inmediata: la estrategia más hábil a favor de una metafísica de aspecto idealista - estrategia tal que nadie resistepone a operar una dialéctica bastante estrecha según la cual la reflexión no debe descansar en el contenido del conocimiento o de nuestras adquisiciones -tarea necesariamente descriptiva, historiográfica o, mejor, recapitulativa-, sino en las condiciones de sus posibilidades, lo que eleva el debate un grado y no deja de profundizarlo. No debemos dedicarnos a pensar "lo que es", sino el porqué de "lo que es" o lo que lo ha hecho tal (proceso trascendental, una palabra que no hemos de confundir con trascendente).

Cómo citar: Dagognet, F. (2021). Cambio de perspectiva; el adentro y el afuera (L. Paláu, trad.). Ciencias Sociales y Educación, 10(19), 279-349. https://doi.org/10.22395/csye.v10n19a10

Traducción realizada por Luis Alfonso Paláu-Castaño del texto de Dagognet (2002).

Agradecemos a la editorial francesa La poner a disposición este material para su divulgación pedagógica en otros idiomas. Nota del editor.

Recibido: 14 de octubre de 2020.

Aprobado: 15 de enero de 2021. 
¿Por qué somos reticentes ante una empresa tal? Si el filósofo se consagra a la búsqueda de este fundamento, gracias al cual el saber habría podido forjarse y validarse, el saber en cuestión no deja de transformarse y emanciparse rápidamente de su primer encuadre o al menos del anterior. En estas condiciones, lo trascendental pierde su razón de ser y cae en lo histórico o lo contingente. Es el "por qué" de un "qué" que a su vez ha sido descoronado y relativizado. Y antes que dirigirse hacia las estructuras del entendimiento que habrían permitido el conocimiento - pues no se evita señalar entonces un ego constitutivo—, valdría más la pena tratar de coincidir con el saber en movimiento, sacar a flote sus grandes líneas, pensarlo en sus transformaciones categoriales y, sobre todo, abandonar la región de un espíritu que cree encontrar solo en sí mismo lo que funda la renovación. Nos parece también que el examen "de las condiciones de posibilidad" se ha elevado demasiado alto, hasta el punto que termina por abandonar el suelo de la verdad en curso y sus mutaciones; reencuentra una infaltable "tabla de las categorías" que no actualiza.

No se trata de declararle una guerra cualquiera al ego, sino que tratamos de conectarlo con cuestiones objetivas en movimiento; lo entregamos a contradicciones que deberá desatar y que lo estimularán. Solo está en el fuego de los problemas. En el texto que sigue trabajaremos para favorecer como para ilustrar la relación entre el yo y la exterioridad, en tanto que lo esencial se desenvuelve en su cruce (la ciencia, la técnica, el arte, los reglamentos jurídicos, las acciones morales, solo se desarrollan en el encuentro entre el pensamiento y sus diversas construcciones o creaciones) ${ }^{1}$.

No defendemos el simple afuera, sino el que construimos, esto es, el afuera de un adentro sin el cual el adentro se anemia y se deshilacha. A la inadecuada pregunta "¿qué soy yo?" conviene entonces responder: solo somos a través de lo que fabricamos o de lo que edificamos. En rigor, incluso esculpimos nuestro cuerpo, nos imprimimos sobre él y podemos leer en él el ser que expresa y expone.

Conocemos otra respuesta que concierne al trabajo del filósofo en su búsqueda de un "objeto" indispensable y en peligro de hundirse en una especie de rumiadura estéril: se encierra en los textos fundadores de los sistemas filosóficos. Por lo demás, solo lo aprobamos parcialmente, pues este estudio únicamente vale si el sabio comentarista recurre a métodos textuales o a instrumentos interpretativos que aclaren de manera inédita la obra en consideración; en caso contrario, solamente se logrará la "redundancia" o volver a decir lo que ya se ha dicho.

No dudamos en añadir a esta lista (no exhaustiva) la religión; retomamos acá una definición de Maurice MerleauPonty (2014): "El cristianismo ha consistido en reemplazar lo absoluto separado por lo absoluto en los hombres" (p. 72). ¿No es preciso que la religión considere como más importante el aspecto práctico (lo sacramental participativo, por no decir el cuerpo societario místico) que las cuestiones teológicas (el lado teórico)? 
Pero hemos tropezado con una objeción —una de las más ácidas y de las más básicas- que tiende a desencallar lo subjetivo y a desviarnos de la objetividad redentora a través de su anotación; consiste en sostener que el hecho de no haber publicado muchos desarrollos filosóficos que no entran en el esquema habitual y que no sirven al campo de la intersubjetividad se debe a que hemos encontrado satisfacciones personales de diversa naturaleza, aunque solo sea el placer de la provocación. No hay nada peor que esto: en esta perspectiva la escritura en sí misma se vuelve su fin (hedónica). El ego, despedido y eliminado en tanto que tal, logra un gran desquite, mientras que continuamos sosteniendo que el filósofo no debe preocuparse por sus afectos o por su contentamiento; que trabaja solamente en la verdad o más exactamente en la comprensión de nuestro mundo en crisis. Acá está su tarea: poco importa que sea agradable o árida eso poco importa. Pero reducir su intervención a ventajas personales implica una visión desdeñosa y da importancia a lo que hemos desterrado (la egología).

Para llevar a cabo su misión, el filósofo debe entrar en las diversas provincias de nuestro universo: los filósofos del pasado no se han atrincherado en la sola filosofía; a su manera han recorrido el mundo y lo han pensado por entero. Debemos seguir su ejemplo. Por nuestra parte, nos felicitamos por habernos beneficiado de las enseñanzas de muchas facultades (Medicina, Ciencias) diferentes de aquella en la cual comenzamos (Filosofía); también hemos conocido algunos de sus problemas, lo que nos ha conducido en un primer momento a reflexionar sobre una disciplina mayor, aunque rara vez la filosofía de las ciencias la haya tenido en cuenta: la morfología (la forma de un cuerpo nos instruye a veces sobre él, mucho más que la atención prestada a su contenido) que a su vez nos conduce a la "sistemática".

Notemos que una de las interrogaciones que se plantea aquí se enuncia de esta manera: ¿del conjunto de los caracteres que nos son ofrecidos y que observamos, cuál hemos de retener como el más constitutivo de los que lo llevan? Todos no están situados en el mismo plano: conviene separar lo adventicio, circunstancial, complementario, parasitario, accesorio y secundario de lo principal, fundamento de todos. ¿Con qué elementos hemos de contar para colocar el ejemplar adecuado de una planta en un herbario? Como se sabe, Linneo reagrupaba bajo una misma categoría las plantas que poseen el mismo número de estambres; luego se inspiraba en su localización con respecto al pistilo central (el método llamado sexual). Pero se sabe que esta partición fracasó porque el naturalista había llevado a cabo escogencias arbitrarias y porque sus criterios no correspondían realmente con la estructura de lo que examinaba. Fue llevado a aproximaciones desautorizadas por la naturaleza y no accedía a las famosas afinidades entre los semejantes. Es preciso, paralelamente, velar por reunir a los que se parecen (especies, géneros, clases, ramas) y no acercar a los que son lejanos. El sistema linneano no resistió: carente de poder 
contar con la equivalencia entre una parte y el todo, en razón de la inconstancia o de la variabilidad del signo en cuestión, el botánico enredó la distribución o el mapa del conjunto. Le tocó a Antoine-Laurent de Jussieu, en lugar de focalizarse en los órganos de la reproducción, guiarse preferencialmente por la reproducción, es decir, la semilla (o el embrión); parte de los cotiledones de acuerdo con que haya dos, uno o ninguno. Este carácter básico entraña los otros. De acá en adelante, puestos en presencia de un vegetal cualquiera y desconocido (por ejemplo, un lirio o una espadaña), podemos eximirnos de lo tocante a la germinación y, por tanto, de la búsqueda del germen (el signo discriminativo), porque hemos señalado los caracteres fáciles de notar y que resultan del principal; ellos lo designan indirectamente (las hojas de nervadura paralela, o también la flor construida sobre el tercer tipo, etc.). En suma, lo que vemos es suficiente para darnos a ver lo que no vemos (en el momento). ínútil disecar o abrir la semilla! Triunfa ya la visibilidad cuando es metódica y organizada. Asimismo, conocemos las propiedades que encierra el vegetal, sus usos, porque los unos y los otros tienen que ver con el grupo en el cual ha sido situado regularmente.

Que la aproximación mórfica convenga tanto a una mejor comprensión de los cuerpos como a la de las construcciones humanas es algo que testimonia aún a favor de esta disciplina (las ciudades, las arquitecturas, los organigramas administrativos, los paisajes). Hemos tratado de evidenciarlo en Por una teoría general de las formas (1975).

Arrastrados por esta corriente hemos concedido mucho a la imagenología, que nos ofrece la vista más completa de la realidad; los grafos dicen muchísimo sobre lo que parecen reducir o simplificar. ¿No contiene el mapa de una región más información de la que oculta lo que observamos directamente sobre el terreno? Hemos examinado la paradoja según la cual el plano o el diseño de una cosa la desborda y, por consiguiente, nos aclara sobre ella; franca confirmación que hemos comentado ampliamente en Tableaux et langages de la chimie (1969): las propiedades de las moléculas arborescentes —especialmente las de la química orgánica - se leen a través de su configuración cada vez más cargada (en símbolos abreviados), pero cada vez más informante, a tal punto que esta ciencia, de experimental que era, tiende a volverse escritural o gráfica.

La morfología y la iconografía nos han conducido naturalmente al examen de los soportes y, por tanto, a una verdadera materiología, antítesis de una metafísica considerada demasiado mentalista, que tiene poco en cuenta a las sustancias a las que solo utiliza como medios, especialmente para llevar o transportar la idea (el pretendido hilemorfismo porque, en esta expresión unitaria, la materia no pierde su rango de servilismo y de inferioridad). Hemos tenido que rehabilitar lo que los materialistas mismos han rebajado, pues la 
noción de materia solo les servía como arma de guerra contra su enemigo, el espiritualismo, mientras que los primeros gérmenes del espíritu (la acción a distancia lo ilustra) se alojan ya dentro de las sustancias despreciadas. El problema de su antagonismo reposaba, entonces, sobre bases falsas.

No satisfechos con esta defensa, hemos llegado hasta entonar el elogio de algunos objetos ordinarios. En este sentido, nos interesa tanto en su propio funcionamiento como en su aspecto (el diseño); por ello, es una objetología declarada.

Finalmente, prosiguiendo siempre por este camino y por numerosas razones, hemos llegado a la rehabilitación de los desechos (la abyectología): todos los artistas han encontrado en estos lo que habría de permitir sus construcciones. Lo debilitado y lo desquijarado llevan consigo mismo, aunque implícitamente, la historia, por no decir los dramas que los han destruido; el desgaste les añade una dimensión a la vez material y social. Lo nuevo y lo intacto sufren por no haber sido aún empleados. Este hecho los inmoviliza y tanto más porque están recubiertos de un unto destinado a asegurar su preservación, sin contar que por esto mismo podrán engañar a causa de su espejeo y de su consiguiente lisura.

Morfología, iconografía, materiología, objetología, abyectología; prolongamos nuestra trayectoria con una exología ilimitada que, a diferencia de la egología, a la cual se opone frontalmente, nos hace girar hacia el exterior que es, por regla general, desclasado y desdeñado. El afuera no goza de un estatuto privilegiado, sino que parece que solamente ocultara el adentro; y si lo protege, lo aísla sobre todo y nos priva de él. ¿No es preciso romper la envoltura bajo la cual se encierra el fruto si deseamos nutrirnos y beneficiarnos de él? ¿Todos los tesoros no están disimulados y colocados en una especie de tabernáculo? ¿No se debe también pelar la más humilde de las legumbres y sacarla de la vaina donde se aloja? Los carapachos obstaculizan o complican por todas partes nuestra empresa; tropezamos con recubrimientos cuya razón de ser comprendemos: asegurar el cuidado de lo precioso y de lo frágil que conviene abrigar.

Pero no nos dejemos engañar por algunas situaciones concretas que van en el sentido de los prejuicios; por lo demás, esta cáscara que recubre el fruto o el grano no deja de entreabrirse con el fin de asegurar la reproducción. Asimismo, la corteza se raja y a menudo debe ser renovada porque nada se gana con madurar en una prisión estanco. El ser no puede ser condenado al repliegue y a la extenuación que de esto resultaría, mientras que por definición él debe irradiar, manifestarse y revelar su potencia.

Hemos llegado a defender "el tener" a tal punto que este acompaña al ser (humano), lo marca y ayuda en su constitución. Para nosotros, "ser" y "tener", lejos 
de excluirse, se compenetran y se llaman el uno al otro. Un sujeto no se concibe sin algunas pertenencias a las cuales permanece apegado; por lo demás, una parte de la vida social de unos está dedicada a arrebatar a los otros lo que los singulariza (la tesaurización inseparable de un empobrecimiento de los que son privados de su riqueza como de sus bienes). La rabia de poseer (y por tanto de desposeer) define una pulsión objetal que rivaliza, por su violencia, con la sexualidad a la que termina por parasitar. Asimismo, cuando una persona se encierra en sí misma y manifiesta una conducta de timidez es porque, sin duda, se prepara para volver al combate que solo ha interrumpido, o bien porque se imagina que a través de su retracción se impondrá a aquellos de los que se aleja, porque son indigentes o groseros; en los dos casos ella continúa creciendo (imaginariamente). No podemos creer ni en la realidad de una existencia enteramente amurallada y cortada de sus semejantes ni en la de conductas de verdadero aislamiento.

La exología, en la cual entramos y que deseamos fundar, debería mostrar la inconsistencia y la falsedad de una interiorización absolutizada; incluso el eremita, retirado al desierto en una lejana tebaida, no se exime de prácticas o de gestos litúrgicos que realiza con tanto más fervor cuanto que ha querido sustraerlos de los riesgos de contaminación; medita también los textos fundamentales (ya estén escritos o solamente rememorados) de su Iglesia o de su religión: con miras a su intensificación interioriza solamente la vida exterior. También piensa, por tanto, habla consigo mismo y, al irse, no deja de recurrir a las palabras de su tribu.

Robinson sigue en su isla en contacto con los otros hombres, porque las herramientas que ha salvado del naufragio, y sin las cuales no saldría adelante, lo mantienen en la civilización y por consiguiente en la sociedad [...] Recuérdese al guarda forestal del que habla Kipling, solo en su casita en medio de una selva de la India. Todas las tardes se viste de negro para cenar. (Bergson, 1962, p. 55)

De esta manera, Bergson, que es uno de los campeones de una interioridad excesiva, reconoce la interpenetración de lo social y de lo individual; no podríamos acceder a lo uno sin pasar por lo otro del que no se separa.

¿Pero cuál es la finalidad más o menos explícita de nuestro análisis? Ante todo, luchamos contra lo que nos sugiere el lenguaje y de lo que no podemos desprendernos; la filosofía cartesiana ha sido ya envenenada con esto. Por ello, casi se nos ha impuesto la idea de que el afuera de una cosa no puede equivaler a la cosa ni informarnos sobre ella, pues este no se sitúa en ella sino solamente en su contorno. De la misma manera que el árbol nos oculta el bosque, así mismo la corteza nos esconde al propio árbol. Siempre parece que el fondo se impone a lo que lo rodea y también lo vela. 
La razón de tal valorización de lo uno en detrimento de lo otro se desprende también de que no hemos sido entrenados en la lectura de superficies que, sin embargo, se vacían lo más frecuentemente sobre lo de abajo y dependen de él. Así, la corteza de la que acabamos de hablar nos permite, por sí sola, identificar la especie; y no dudamos que eventualmente las modificaciones que la afectan traducen el vigor de tal o cual plantación. El aparecer es suficiente para decir el ser que no deja nunca de exhibirse por algún lado; por lo demás, si se sabe que "ocultar es mostrar", ganamos al no caer en la seudodisimulación; seguramente que nos traicionará.

Pero enfrentamos patentemente algo más: es claro que salimos en guerra contra la filosofía de la "interiorización ideal"; queremos quebrar o al menos discutir la más antigua de las divisiones, la que opone al pensador, que no se baña en las cosas y que no se arriesga a ser contaminado por ellas (la santuarización protegida o la clericatura de los especulativos) y con el cual solamente ejecuta y manipula. El primero se imagina que puede elevarse hasta aquello cuya existencia ni siquiera sospecha el otro, impotente para abandonar la caverna en la cual está encadenado. Esta hendidura recorta lo que separa el pensamiento del cuerpo (el dualismo tradicional e inveterado), lo puro de lo impuro y lo espiritual de lo material.

En los capítulos que siguen nos dedicaremos a mostrar que la idea verdadera no se distingue de sus aplicaciones, sino que solo vive por ellas; la materialidad, en vez de ignorar lo espiritual o anularlo, lo ajuicia y lo sirve; asegura al menos su fecundidad.

Mientras hacemos la ruta, atacaremos los bastiones de la filosofía clásica, el cerebralismo (el solo cerebro como a caja que contiene todas las facultades), el puro cogito, la búsqueda de lo invisible o el descenso a los pretendidos arcanos del universo, en resumen, todos los restos del kantismo, es decir, de la noumenología (el noúmeno designa el en-sí que no podríamos alcanzar). Por lo demás, el kantismo creía ser una "revolución copernicana", pero nos propuso lo inverso; para él las cosas giraban en torno al pensamiento situado en el centro y regulador de todo el sistema. Pero el pensamiento se debe plegar a las cosas; debemos desalojarlo de una posición demasiado dominante.

Abandonaremos este punto de vista y todas sus ramificaciones que nos han engañado pero que servían principalmente a un designio sociopolítico. $\mathrm{El}$ angelismo de consciencia e ideal va de la mano con juicios desigualitarios y deshumanizantes. Le da ventaja a una élite (la intelectual) que termina por perderse al confinarse en su aislamiento. 


\section{Capítulo I. El bipolo "órganos sensoriales-cerebro"}

Comenzamos nuestro examen por el estudio de la sensación con el deseo de comprenderla de manera que sirva a "nuestra perspectiva" que otras obras han desarrollado en lugar de debilitarla. No fabricamos otros filosofemas, sino que explicitamos los más antiguos ${ }^{2}$.

La sensación es generalmente considerada como "una especie de choque" por parte de un real que sacude al sujeto y le avisa de lo que lo rodea; sin embargo, este debe interpretar una tal señal que a veces lo engaña. En efecto, recibimos una información a menudo trunca, incluso confusa y siempre global en el sentido de que el conjunto se impone sobre los detalles y nos los esconde; no accedemos a las partes sumergidas en el "todo" que es lo único que retenemos. La ilusión de Muller-Lyer, frecuentemente comentada, lo subraya: dos rectas iguales se desigualan casi necesariamente cuando a una de ellas se le coloque puntas de flecha en sus dos extremos; entonces esta se alarga mientras que la otra, reducida a sí misma, parece disminuir. De la misma manera, no registramos tal o cual dato, sino a través de los otros que lo escoltan o lo preceden: un gramo añadido a un kilogramo no es percibido, pero sin duda lo sería si fuese agregado a otro gramo. Solo somos sensibles a diferencias. Y todas estas experiencias terminan por relativizar el sentir. De esta forma, este real que nos golpea solo sería admitido o comprendido en función de nuestra receptividad o, incluso, de nuestra propia posición anterior; es lo mismo que decir que solo entra en nosotros coloreado o instituido por nosotros.

Nos opondremos a esta explicación y preconizaremos una teoría resueltamente exteriorista (o externalista). Creemos poder e incluso tener que reducir la omnipotencia del sujeto; reconocemos la importancia de lo real que viene a imprimirse en nosotros. Por consiguiente, disminuiremos la parte de la interpretación que considera que interviene en la percepción, recubriéndola y yendo hasta el debilitamiento, por no decir hasta la casi anulación de lo que la suscita (el estímulo).

Por lo demás, como trataremos de mostrarlo, el yo no se sitúa allí donde lo disponemos, una profundidad donde se agazaparía y desde donde juzgaría y decidiría. Él no está dentro de nosotros, sino perfectamente afuera. Se realiza primero en la sensación misma, al mismo tiempo que esta lo constituye y lo arrastra, a él y a su acompañamiento cerebral. El yo no recibe informaciones para evaluarlas, sino que la operación sensorial, que nos permite el acceso a lo real (el afuera), sirve curiosamente para la emergencia de la conciencia o del yo.

Nos proponemos favorecer una "exteriología" que tomará el lugar del ego, de la egología, cuya validez discutiremos. La exteriología prolonga la secuencia "materiología, morfología, objetología, abyectología". Le concedemos valor a un "afuera" que nos parece el verdadero adentro. Nota del traductor. 
En este sentido, no consideramos a este como un antecedente o una condición de aquella, sino como su efecto.

Nuestro primer adversario se llama Berkeley porque él ha tratado y expuesto la argumentación más vertiginosa y, según nosotros, la más falsa, al mismo tiempo que el desvanecimiento del excitante (iguerra al sustrato material!) y la inflación consciencial. Lo que se creía ingenuamente "objetivo" solo se desenvuelve en nosotros. Veamos una breve muestra de su concepción:

No se debe decir por ejemplo que el azúcar es dulce y que el absintio es amargo porque tanto el uno como el otro - el dulzor o la amargura - tienen que ver con el placer o con el desagrado (el dolor) que son apreciaciones subjetivas las dos y que no podrían encontrarse en las cosas mismas. (Berkeley, 1944, p. 29)

Por lo demás, según Berkeley, lo que le parece dulce a uno podrá ser experimentado como amargo por un paladar enfermo o descompuesto. "Personas diferentes encuentran en los mismos platos sabores diferentes; lo que le gusta al uno otro lo detesta" (Berkeley, 1944, p. 29).

Igualmente, lo suave debe ser aproximado a lo friable (como lo duro de la solidez). Ahora bien, según Berkeley, "es evidente que lo que parece duro a un ser animado puede parecerle suave a otro que tenga más fuerza y vigor en los miembros" (Berkeley, 1944, p. 51). La resistencia que creemos experimentar no se encuentra en los cuerpos: "¿Podréis creer, añadirá Berkeley, que los detritos y las basuras afecten a los animales inferiores, que se nutren de ellos indiferentemente, con los mismos olores que percibimos nosotros en ellos? (Berkeley, 1944, p. 29).

Berkeley no ha dejado de retomar la distinción entre las cualidades secundarias (el sabor, el olor, el color) y las cualidades primarias.

Por estas, escribe entonces Berkeley, entienden: extensión, forma, movimiento, reposo, solidez o impenetrabilidad y número[...] Sostienen que nuestras ideas de cualidades primeras son los tipos o las imágenes de cosas que existen por fuera de la inteligencia, en una sustancia no pensante que llaman materia... Pero es evidente, por lo que hemos mostrado, que la extensión, la forma y el movimiento solo son ideas que existen en la mente. (Berkeley, 1968, p. 113)

Berkeley no podía dejar de "desobjetivar" esas pretendidas cualidades primarias y alinearlas sobre las otras, las secundarias, menos consistentes:

Cuando nos aproximamos o nos alejamos de un objeto, la extensión visible varía, y a una distancia dada es diez o cien veces más grande que otra distancia. ¿No resulta de esto pues que ella no es realmente inherente al objeto? (Berkeley, 1968, p. 113) 
El argumento no nos convence; el simple hecho de que "la espacialidad" varíe con nuestra posición (proximidad o alejamiento) solamente nos prueba que obtenemos aquí una doble información: una que tiene que ver con el objeto (su volumen aparente) y la otra con su distancia con respecto a nosotros, lo que es una indicación particularmente útil. Pero Berkeley, el autor del famoso esse est percipi, tiende a quitarle realidad a lo percibido que se confunde entonces con nuestra reacción psicofisiológica, sin remitir a un sustrato.

El idealismo de Kant (llamado trascendental), a pesar de la fosa que lo separa del idealismo subjetivo de Berkeley, se le añade: en efecto, los dos, con argumentos que no se comparan, no dejan de amplificar la parte del sujeto en lo que él experimenta. Y si Berkeley considera, por este mismo hecho, "al en-sí" (la sustancia exterior) como inexistente, Kant la juzga "incognoscible". Y Kant reconoce también que los sabores y los olores solo dependen de nosotros y no se alojan en los objetos ("el agradable gusto de un vino no pertenece a las propiedades objetivas de ese vino... sino a la naturaleza particular del sujeto que lo disfruta"). En cuanto al espacio y al tiempo, los dos definen las condiciones necesarias de toda representación, pero reemplazan por entero nuestra sensibilidad que marca así todo lo que recibimos y lo que nos priva del acceso directo a lo real, obligatoriamente sometido a nuestro propio cuadro.

Nuestra sensibilidad está sometida siempre a las condiciones de espacio y tiempo, originariamente inherentes al sujeto. El más claro conocimiento del fenómeno de los objetos, que es lo único que de ellos nos es dado, jamás nos haría conocer en qué consisten en sí mismos. (Kant, 1978, p. 83)

No tomaremos por este camino. ¿Cómo concebir entonces "el sentir"? De entrada, nos aprestamos a discutir la importancia que se le concede a la separación entre la sensación y la percepción. Esta última se sobreañadiría a la anterior con el fin de interpretarla y de sacar de ella informaciones útiles; sin esta adición o este concurso - gracias a la reflexión, al juicio, a la memoria, al hábito- la primera (lo sensorial) equivaldría a "casi nada", a una especie de simple sacudida orgánica (compresión, vibración, variación). Nos tenemos que preguntar en este momento en qué podría consistir la interpretación si el material que hay que analizar o concebir carece a tal punto de contenido o de significación. Además de no tener conciencia de esta división en la operación que se realiza en lo instantáneo, creemos discernir en la pretendida ayuda de la una a la otra, un medio de rebajar la "receptividad".

Por lo demás, es fácil aminorar esta parte llamada de la excitabilidad: ella misma está ya encerrada en límites bastante estrechos (los umbrales inferior y superior, que son difíciles de medir). Además, sabemos que nos acostumbramos rápido a un ruido o a un olor a tal punto que dejan incluso de ser escuchados o 
reconocidos; esta insensibilidad vendría de que la persistencia de la impresión objetiva (y olfativa) termina por aminorarla hasta el punto de abolirla. Por ello, la mucosa nasal de algunos individuos permanece insensible a los "olores que ellos mismos exhalan". Solo incomodan a los otros, pero ellos mismos escapan a ese desagrado.

Vamos a retomar algunos de los bellos análisis de Maurice Pradines que nos ha persuadido de que la actividad sensorial corresponde a una victoria del organismo más evolucionado. En efecto, lo que caracteriza al hombre no se aloja en sus repliegues corporales (lo visceral sordo y por tanto obtuso), sino, como lo veremos, en la punta de sus dedos, en su periferia. Los seres inferiores, los animales menos diferenciados (los hiponeurianos) han optado por la estrategia defensiva más rudimentaria; se rodean de un sólido caparazón; una parte del sistema óseo en ellos tapiza su superficie (el exoesqueleto).

Nos es suficiente con comparar el tacto del hombre y el del animal: los pelos (sedas, crines, lanas), las plumas y lo córneo recubren el cuerpo de las bestias. Seguramente los monos poseen cuatro miembros terminados en manos. Sin embargo, además de que estos cuadrumanos no pueden mover sus dedos separadamente y que el pulgar no puede ser opuesto a estos últimos, la palma de estas extremidades no deja de estar revestida por una especie de costra callosa. En cuanto a los solípedos, los rumiantes y los carnívoros de todo orden, disponen todos en su periferia de pezuñas, garras, cascos; otros prefieren recibir una impresión bastante vaga ora por la nariz en forma de hocico o de trompa, ora con la ayuda de pelos rígidos que registran las sacudidas (el bigote del gato, las tunas del erizo o del puerco espín). En cuanto a las aves, cuyas patas están recubiertas de escamas y el cuerpo de plumas, deberán recurrir al pico para tocar.

Todos estos animales pagan caro su cuasi encierro protector (son separados de un mundo que solo muy parcialmente pueden alcanzar). Solamente lo más nocivo los alerta. Los menos favorecidos (los hiponeurianos) sufren de una relativa inmovilidad y, sobre todo, de una apatía incurable; van a vivir en la hibernación.

Por ello, los más ingeniosos, los más sutiles (los epineurianos) van a ganar la batalla de la evolución: van a invertir su estructura; se dan vuelta de tal manera que a pesar de torsiones o de recubrimientos tisulares, logran desplazar "la solidez, es decir lo óseo"; lo meten adentro y se apoyan en él, mientras que la sensibilidad va a ocupar el afuera de ahora en adelante. ¿Qué van a hacer desde entonces para evitar el peligro que los amenaza? Los cinco sentidos - y más particularmente la vista y el oído- se afinan y se vuelven capaces de recibir los estímulos más débiles posibles, pues están situados por debajo del umbral reflexógeno. Los aparatos de registro se definen porque reaccionan a 
fuentes lejanas; por lo demás, la distancia entre el excitante y el receptor permite evaluar la finura y la superioridad de lo sensitivo-sensorial.

Otra característica: lo "sensorial" no experimenta lo que lo afecta; debido a su minimalidad, la insensibilidad orgánica se parece más un afloramiento y lo refiere inmediatamente a lo que lo ocasiona (el objeto). Desde que vemos sabemos lo que acaba de impresionarnos, pues comenzamos a distinguir, aunque confusamente, la forma, las dimensiones, el relieve, el tamaño y el alejamiento.

Las medidas obtenidas por Weber, con la ayuda de su estesiómetro, permiten explorar el tacto, diferenciarlo de sí mismo y determinar la distancia que se necesita dar a dos puntas de un compás que tocan al mismo tiempo la piel para que esas dos puntas produzcan dos impresiones separadas y sentidas aisladamente. Este procedimiento nos permite conocer la finura de tal o cual región; podemos incluso construir una escala de la sensibilidad táctil (a la presión). De esta manera, para la región mediana de la espalda, las puntas deben estar separadas seis centímetros, mientras que el antebrazo solo exige tres centímetros; pero el récord lo obtiene la yema de nuestros dedos (tres milímetros) y sobre todo la punta de la lengua (un milímetro). Si excluimos esta última prestación, claramente la mano (la punta misma de los dedos) es la más experta para juzgar sobre la consistencia, los contornos y el pulido (o la rugosidad) de lo que tocamos o exploramos. Es preciso subrayarlo: acá como allá tomamos consciencia, por un lado, de la sede de la zona excitada - y sabemos localizar la sensación-; pero, por otro lado, identificamos y reconocemos las dos puntas que nos afectan. Nos orientamos en el campo táctil; referimos siempre al afuera (a la periferia) la modificación experimentada (la exteriorización y la localización no faltan aquí).

El yo acaba de vencer: se construye poco a poco un mundo. Notemos, sin embargo, que la evaluación de Weber podría arrastrarnos al error: el experimentador solo usa dos puntas mientras que el universo que nos rodea nos golpea con excitantes reales, variados y que tienen volúmenes. En este contexto, el estímulo se reduce a tal punto que se limita a ser "puntual" (el objeto es volatilizado). Estamos demasiado centrados sobre el órgano receptor, mientras que lo importante se encuentra en lo que recibe.

Ya no estamos encerrados en lo visceral (un abisal mudo, ciego y errático); hemos logrado disponer en nuestra extremidad (la interfaz entre el mundo y nosotros, por tanto, el lugar sensible de los posibles intercambios), que nos permite ser informados y advertidos, en la punta de nuestros dedos y de nuestra lengua, por medio de verdaderos centinelas. Acogemos aquí impresiones (que no son de ninguna manera presiones) insensibles por sí mismas, tan débiles que no podríamos experimentarlas y que, por esto mismo, las remitimos a sus causas. 
A veces utilizamos una astucia para ser informados: la planchadora, para apreciar el calor de su plancha, toca por un instante extremadamente breve con su dedo mojado o la aproxima a la mejilla. Sustituye la distancia espacial (una distancia de la que se benefician sobre todo el oído y la vista) por algo temporal, la brevedad de una aproximación tal que impide verdaderamente el contacto; siente, pero no experimenta; no le da suficiente duración a esa aproximación para que pueda "quemarla". De esta manera, subsiste la separación indispensable para que nazca la sensación (el tacto no equivale a un contacto).

Nos parece evidente que nuestros órganos sensoriales conocen inmediatamente, sin análisis o trabajo interpretativo (veremos ulteriormente en qué consiste), la naturaleza de lo que los afecta (débilmente), su intensidad y, a través de esta, su distancia. La información de base nos es dada en el momento mismo en que la recibimos: lo sensible y lo inteligible son una y la misma cosa. Por consiguiente, evitamos ya los dos principales callejones sin salida en los cuales se hunden buen número de metafísicos. En efecto, los unos defienden el dualismo, que opone el espíritu al cuerpo, mientras los otros reabsorben aquél en este, lo que conduce no tanto a resolver el problema como a suprimirlo. Es verdad que al separarlos nos privamos de comprender cómo podemos mover nuestro cuerpo y también cómo este puede informar la consciencia (en efecto no se ve cómo la materia influiría en el psiquismo). Y en cuanto a la antigua hipótesis cartesiana de una glándula pineal susceptible de asegurar el pasaje entre el alma y el cuerpo, no le podemos prestar atención, pues tiene que ver con la fantasía y la comodidad: se trataría de un órgano puntiforme (un solo punto localizado en medio del cerebro que se prevaldría de lo inextenso), pero que, a pesar de todo, de su extrema disminución material, aún es espacial. En resumen, este pretendido medio de intercambio y de contacto padece contradicción (es a la vez extenso e inextenso).

Pero el solo y simple hecho que recogemos con la sensación, datos mínimos y directamente expresivos, prueba ante todo que no hemos abandonado la esfera de lo somático (el lado material); sin embargo, el cuerpo solo recibe avisos (el lado estrictamente informacional). Los dos registros comienzan a fundirse o a conjugarse. Hemos insistido suficientemente en esto: lo representativo surge porque ya no estamos tocados por irritantes ni afectados por ningún peligro, solamente estamos prevenidos por esto; lo sensorial alerta al sujeto que sabe a qué atenerse. De esta manera, creemos evitar tanto la concepción dual como la teoría unitaria, solamente material, pues el nuevo estímulo ya no nos da un choque, sino una anticipación: podremos aproximarnos al objeto buscando tomarlo o alejarnos de él si presentimos un peligro. El espacio y el tiempo se abren pues ante nosotros. La sensación infrarreflexógena entraña estas consecuencias. 
Sin embargo, distinguiremos, entre los órganos de registro, los más pobres (el gusto y el olfato) de los más evolucionados (la vista y el oído): los jerarquizaremos en función de la distancia entre sí y lo que ellos nos indican a lo lejos. Por ejemplo, el oído no ha dejado de afinarse: debió sustituir la simple presión de un sólido sobre él por un intermediario líquido, menos limitado, más receptivo y por ende más sensible (propio de los peces); luego reemplazó este último por uno aéreo para lograr advertencias más discriminativas. La arquitectura auricular nos muestra este trabajo gracias al cual podemos recibir ruidos alejados y débiles. Pero la oreja ya no soporta más ni el exceso ni lo demasiado próximo.

En cuanto a la vista, ella nos da lo máximo: la presencia, la forma, el lugar, la intensidad y, sobre todo, el intervalo probable entre nosotros y lo que nos avisa. No podemos recibir la luz propiamente dicha; no podríamos mirar el sol directamente, solamente sus efectos, los reflejos. Maurice Pradines (1943) lo ha notado claramente:

Este afinamiento aparente a la luz es, en realidad, un afinamiento a los reflejos de la luz enviados por sólidos aclarados, y tiene por efecto informar al ser viviente sobre la presencia, el sitio y la forma de esos sólidos. Es solo por el beneficio de esta transformación que la sensibilidad a la luz se ha vuelto una sensibilidad sensorial... Lo luminoso es, bajo ciertos respectos, lo contrario de la luz, lo que la rechaza o reenvía. (pp. 532-533)

Cantidad de objeciones se presentan contra esta manera de ver; responderemos a ellas poco a poco, pero no hemos hesitado poner el ego por fuera de sí mismo, por así decirlo, en lugar de hacerle una barricada en una especie de enclave cerrado donde se atrincheraría. Creemos apercibirlo ya en esta primera construcción que es lo sensorial (seguido de sus efectos motores). ¿Pero no es el yo el que trabaja para esta victoria? Más bien él resulta de todo esto. No olvidemos que el encéfalo pertenece a la misma hoja embriológica de lo cutáneo: lo uno no se desarrolla sin lo otro. Por lo demás, uno y otro se han hecho más complejos y más sutiles juntos a través del abandono del estadio rinencefálico: este le daba más ventaja a los olores y los sabores que se definían por la débil distancia entre el estímulo y la reacción; privilegian pues "la proximidad" pero, por ello mismo, colocan al viviente ante la precariedad y el peligro. También este viviente en dificultades se apresura a acceder al estadio del neopallium, una neocorteza que representa hasta el $85 \%$ del volumen total del encéfalo, que constituye sobre todo la parte de adelante de este cerebro ("la majestad del llamado cerebro", según la expresión de Gratiolet). Encierra los lóbulos del cerebro, entre ellos el frontal: concreta a su manera el rebasamiento señalado en el sentido que la atenuación de la afectividad hace posible de acá en adelante la representación y, por tanto, el reconocimiento de los objetos externos, así como otras operaciones de las que hablaremos posteriormente. 
Continuamos concediendo una extrema importancia a lo cutáneo cuando se revela diferenciado y capaz de captar lo mínimo. Por consiguiente, oponemos el tegumento, con sus órganos sensoriales (una especie de cerebro periférico), al cuerpo visceral, una masa dominada por el funcionamiento que estudia la fisiología de las regulaciones y de las constantes automantenidas. No dudamos en retomar a Bichat (1800) que había señalado, en sus Investigaciones sobre la vida y la muerte, la existencia de dos vidas en nosotros: la estrictamente orgánica y la animal. Por lo demás, esta es intermitente - la sucesión de la vigilia y el sueño- mientras que la otra no conoce interrupción. La vida animal (sensoriomotriz) nace, además, después de la primera y muere antes. La una está solamente injertada en la otra. Bichat y Pichot (1994) las individualiza sin descanso, por ejemplo:

El estómago es sensible a la presencia de los alimentos, el corazón al abordaje de la sangre, el conducto excretor al contacto del fluido que le es propio, pero el término de esta sensibilidad es el órgano mismo, ella no rebasa sus límites. La piel, los ojos, las orejas, las membranas de la nariz, de la boca, todas las superficies mucosas en su origen, etc., sienten la impresión de los cuerpos que los tocan y la transmiten al cerebro. (arts. 7, 3)

Mientras más abandonemos una de estas dos vidas a la biomaterialidad, tanto más reivindicaremos un estatuto diferente para la otra, esto es, allí donde lo sensible y lo inteligible se unen.

Primera objeción a nuestra filosofía de la "sensación": ¿no están provistos la mayor parte de los mamíferos y de las aves de los mismos aparatos receptores nuestros, aquellos por los cuales hemos creído poder caracterizar al propio yo? Incluso hay más: algunos animales nos aventajan; no los reptiles o los batracios que permanecen sujetos a lo olfativo y al cuasicontacto (permanecen bajo el imperio del rinencéfalo), sino otros que se han emancipado de lo que los limitaba, como el águila que discierne desde lo alto, en el paisaje, el menor movimiento que se nos escapa, el murciélago que recibe vibraciones que nosotros no podríamos registrar (los ultrasonidos) u otros capaces de las más seguras y variadas detecciones.

A través de esta anotación podríamos olvidar la segunda mutación, esto es, una inversión que va a cambiar por completo la sensorialidad, una revolución a la cual no accede el animal; solo se beneficia de la primera, aquella por la cual transforma la impresión (lo mínimo, no experimentado como tal) en una señal informacional.

Solo el hombre es capaz de fabricar sonidos (la naturaleza solo emite ruidos) como de autonomizar líneas y colores, de acá en adelante todos sin el lastre de su 
carga indicadora, utilitaria y anticipadora. Para este efecto el hombre va a construir instrumentos o servirse de su voz para liberar el sonido del objeto sonoro:

No es el sonido incorporado al objeto que podemos producir y, por ejemplo, el murmullo que señala la fuente es el sonido desincorporado del objeto, el murmullo sin la fuente. Es necesario sacar el sonido del objeto para meterlo en nuestra laringe, imitar en él no el signo de una cosa que no podemos ser sino el producto de su operación que podemos rehacer, si captamos el mecanismo. (Pradines, 1948, p. 220)

Estamos obligados aquí a abrir un largo paréntesis, pues creemos distanciarnos de Kant; en efecto, en la Crítica del juicio llega hasta desear que no se pueda desprender el sonido o el canto del ruiseñor que se dedica a él. El filósofo se confiesa incluso particularmente molesto cuando se entera que un muchacho malicioso, oculto en el soto, ha logrado imitar al pájaro y hacerse pasar por él. En estas condiciones, según Kant, el canto pierde su referencia, sus más viejas ataduras; debemos renunciar a la profundidad y a la belleza que solo la naturaleza mantiene en secreto. Habría habido engaño y profanación.

El canto de los pájaros anuncia, con su existencia, la alegría y el contento... Pero este interés que nos inspira la belleza en este caso, necesita de todo punto que la belleza lo sea de la naturaleza, y desaparece totalmente en cuanto advertimos que estamos en un error y que solo es arte, hasta el punto que luego el gusto no puede encontrar nada bello en ello, ni nada atractivo la vista. ¿Qué más ensalzado por los poetas que la arrebatadora belleza del trino del ruiseñor en un soto solitario a la suave luz de la luna en una serena noche de verano? Y sin embargo, se sabe de más de un anfitrión bromista que teniendo a huéspedes deseosos de gozar de los aires del campo, y no disponiendo de semejante cantor, los había engañado... Pero una vez convencidos del engaño, nadie soportará mucho tiempo ese canto que antes encontrará tan atractivo. (Kant, 1968, p. 147)

Sin cesar, Kant regresa sobre lo mismo; llega hasta prohibirle al hombre de arte o a la coral rivalizar con los logros de la naturaleza:

El canto de las aves que no podemos reducir a ninguna regla de música parece tener más libertad de vuelo y por consiguiente dar más al gusto que el canto mismo del hombre dirigido no obstante según todas las reglas del arte; en efecto, nos fatigamos más pronto de este cuando se repite con frecuencia y durante mucho tiempo. (Kant, 1968, p. 147)

Pero no entendemos bien lo que el ruiseñor, en carne y huesos, añade a la melodía. ¿Además, a través de su ejemplo, Kant no estará defendiendo un viejo "cliché", el canto de ese ruiseñor al claro de luna? Sobre todo, los sonidos, aunque sacados de alguna manera del pájaro, no han sido verdaderamente liberados; aseguran una función de engaño o incluso, sin jugar al ardid, esperan realizar una proeza: el canto del ruiseñor sin el ruiseñor; un fin diferente de ellos mismos los comanda, lo que por parte de Kant debería entrañar su exclusión del dominio estético. 
El arte verdadero consiste precisamente en "desfuncionalizar" lo que él integra con el fin de que podamos acceder a una "forma" sin un fondo que lo arrebate y lo aliene. Como lo subrayaba Valéry (1957), "no hay verdadero sentido de un texto. No hay autoridad del autor", no hay un lado de acá. En este sentido afirma:

Si me interrogan pues, si se preocupan (como ocurre y a veces de manera bastante vehemente) por lo que he querido decir en tal poema, respondo que no he querido decir sino hacer, y que fue la intención de hacer la que ha querido lo que he dicho. (Valéry, 1957, p. 1503)

Aprovechamos aquí la ocasión —la de nuestro paréntesis- para expresar nuestras dudas con respecto al argumento de la "profundidad", especialmente la que Kant le asigna a la naturaleza. Por lo demás, el ruiseñor no podría sostener un tal papel: su canto no proclama tanto el goce de existir, sino su obediencia a una función vital de asegurar la coherencia del grupo, concretar y seducir una de las hembras que lo escoltan. No seguiremos pues a Kant; la "profundidad" que invoca - a favor de la melodía de su pájaro de noche, símbolo de la naturaleza - conduce a recurrir a una creencia, la de un en-sí insondable e intocable que nadie podría "plagiar" o copiar; el filósofo trata de imponer una pretendida superioridad de "lo que es" y de limitar, por consiguiente, las prerrogativas de un artista-demiurgo de otro universo.

Por una parte, gracias a la neosensorialidad sustituimos un universo que nos rodea, pero también nos presiona (aunque hayamos aflojado el lazo y podamos anticipar el acontecimiento), un mundo que edificamos nosotros mismos (la tecnosfera). Por otra parte, es claro que evolucionamos dentro de un conjunto humanizado (de los objetos que fabricamos, los colores que inventamos y las voces que nos proponen mensajes).

La sensibilidad ha cambiado de naturaleza: nos sumerge en lo social. Seguramente continúa pesando sobre ella una condena que le han infligido los ascetas y los puritanos sin apercibirse que eventuales excesos 0 incluso posibles depravaciones no podrían empañar el principio de base, a saber, que la sensación define o constituye la profundidad verdadera del psiquismo, el éxito mismo de lo corporal (la interfaz entre él y el mundo). E incidentalmente cruzamos aquí al Gide de los alimentos terrestres: ien lugar de desarrollar las reprobaciones, más bien favorece el fervor!

La sensibilidad (y diríamos también claramente "la sensualidad", puesto que le quitamos al término su veneno, como la sensorialidad) ha conocido la tempestad: lo olfativo y lo gustativo retroceden (por lo demás en demasía, pues con ellos gustamos la proximidad de lo real) cuando lo visual y lo auditivo salen modificados y exaltados; no se abren a representaciones, sino a 
"presencias"; abandonamos la vida de las necesidades y de las amenazas por la de los símbolos.

En cuanto al animal, este no abandona el primer grado de las atracciones y de las precauciones mientras que nuestros sentidos superiores acaban de permitirnos la entrada en el arte, un modo nuevo y espiritual de sentir que solo puede existir para un espíritu desembarazado de las tareas a las cuales estaba avasallado; de ahora en adelante, con la pintura y la música, el espíritu mismo se vuelve sensible a la vista y al oído.

Nos es menester añadir una mutación a la precedente: ella la corona. En efecto, los objetos que nos rodean (el vaso de agua) van a ser ventajosamente reemplazados por las palabras que los designan. El excitante no escapaba a lo concreto, a lo singular, a lo circunstancial; ientonces salvémoslo de esta inmersión en la particularidad que lo perdía! Sustituimos pues el dato por una denominación ("el vaso de agua") que sugiere un continente funcional (el vaso) y, en este, un líquido fácilmente mantenido. El sustantivo (el agua) -él solo- implica un verdadero trabajo, porque fabricamos un "ser" del que solo conocemos o experimentamos aspectos bastantes variables (un agua fría o caliente, ruidosa en un chorro o en la fuente, pero silenciosa en su capa líquida). Con las palabras acabamos de elevarnos un grado, sin olvidar que, en ausencia de lo que la palabra designa (el vaso de agua), podemos de acá en adelante evocarlo y así hacerlo presente. Más tarde la ciencia reemplazará esta especie de etiqueta por una notación más rigurosa que nos dirá más sobre lo que ella expresa que la cosa misma (confusa e incierta).

Ciertamente, la operación designativa comporta el grave peligro de abandonar lo real y solo circular entre palabras, creadoras de entidades imaginarias. El filósofo pagará caro una tal ruptura de contacto; le será necesario luchar contra una tal desviación que lo tienta (el nominalismo) y asegurarse siempre del acuerdo entre lo que decimos y lo que se expresa.

Veamos una muestra de esta desvinculación: ¿existe en sí mismo o por sí mismo el "sentir" que tratamos? iPues no! Puesto que en el "sentir" no sentimos (o resentimos) nada; solamente somos puestos en presencia de una escena o de un objeto alejado. La sensación remite siempre a un "objeto situado a distancia", que no es una cosa sino una señal o una información; no somos prevenidos de lo "real", sino más bien de lo que nos espera según nuestra conducta: una especie de anticipación virtual. El solo "sentir" nos induce a error y nos engaña; solo le conviene al que tiende a disminuir la parte del exterior con el fin de agrandar —abusiva, ficticiamente- la participación subjetiva. 
Según la segunda objeción que nos acecha, habríamos ignorado la importancia de lo cerebral en el acto perceptivo. Ahora bien, el teórico se aferra a esto porque, de esta manera, regresa a lo que hemos vituperado: la disminución del estímulo y el peso reconocido a nuestra intervención interpretativa; cae así en un "idealismo psicológico" porque nuestro mundo nacería de nuestra construcción o de nuestra memoria que permite la descodificación.

Una prueba experimental de ello es aportada a través de la experiencia operada con la ayuda del taquistoscopio: palabras corrientes aparecen en una pantalla un tiempo extremadamente breve. Mientras que un décimo de segundo le es suficiente a un lector para que lo proyectado sea reconocido o identificado, se va a requerir triplicar la duración de exposición para que el sujeto aperciba los que le son desconocidos o los que rara vez emplea. Desconciertan y solo son registrados con lentitud, lo que pone en evidencia el papel que juega la influencia central que determina lo que recibimos.

No podremos negar la entrada del recuerdo o del prejuicio ni del empleo en la lectura de lo que vemos. Pero si es indudable que intervenimos con el fin de completar o de captar mejor algunos elementos sensoriales, ¿no es preciso admitir previamente en estos un mínimo de consistencia o de contenido? ¿Cómo escoger lo que lo enriquecerá si este falta? No dudamos que se pueda aprender a ver mejor, pero comenzamos por ver; en caso contrario todo el dispositivo se desfonda y no podemos partir de nada. Seguramente, la sensación se prolonga y se aclara gracias a adiciones que vienen del centro en beneficio de la periferia, pero después de que esta ha alertado al centro y le ha fijado de alguna manera la naturaleza de su concurso. En este sentido, la consideramos el "director de orquesta" de la operación.

Es verdad que lo cerebral no solamente pone el pasado al servicio del presente, sino que sobre todo provee la reacción motriz consecutiva (ya el reflejo medular — lo nervioso elemental— no separa el estímulo de la réplica instantánea que sigue; asimismo, el cerebro asegurará los dos: la información que completa, pero también la acción por la cual responde).

Esta cerebralidad, que juzgamos equivocadamente, debe ser concebida como un amplio conjunto interneurónico: lo que entra (veo un vaso de agua) se engancha rápidamente sobre el acto de beber, pues el instinto acá se impone y no podemos esperar, o bien - porque lo pulsional pesa menos - el dato que se refleja en el cerebro se remite a un mecanismo de inhibición, pues nuestra educación nos ha enseñado el rechazo del deseo y la obligación de prever el porvenir (beberé más tarde). Finalmente, funciona una red de encadenamientos, un cableado complejo que ha instalado el pasado (recuerdos, por tanto, enlaces, reglas o preceptos, consignas, por no decir cálculos). No tenemos, en 
este sentido, ninguna necesidad de recurrir a un "homunculus" oculto en los pliegues de la sustancia gris, que tiraría de los hilos y que tomaría la decisión, ni de localizar aquí un "fantasma de libertad" que sería llamado a deliberar y después a zanjar. En verdad, si estamos deshidratados, desde que A surge (el vaso de agua cuyos efectos conocemos), B (voy a beber) lo acompaña; o también nos deslizamos y solo le prestamos un poco de atención a lo que percibimos.

Si lo cerebral, que no hemos perdido de vista, completa la información recibida, saca también las consecuencias, pero estas le han sido ofrecidas por nuestras sensaciones anteriores que se conservan en él (es un dar por un tomar). Y no vemos en esta doble intervención central (que juega tanto en el ámbito sensorial como motor) algo que permita limitar o disminuir la importancia de lo periférico, allí donde continuamos alojando lo esencial del yo. Este último habita el lugar decisivo, sensible y sobre todo interfacial (lo cutáneo invaginado y transformado en aparato registrador), puesto que el mundo se deposita de alguna manera allí, no bajo la forma de una sacudida, de un desvanecimiento o incluso de un choque, sino - como lo sabemos- como una información o el anuncio de lo que nos está reservado, en función de las decisiones que vamos a tomar. En resumen,

\footnotetext{
"lo sentido" está ya en la "sensación" primera; si concebimos esta demasiado mecánicamente, sin el espíritu que sin embargo la ha investido o al menos que ella encierra (puesto que ella nos da "una información"), no comprenderemos nunca cómo podemos inspirarnos o recurrir a ella; retomamos la fórmula de Pradines: "Para que nuestro pensamiento salga de nuestras sensaciones es preciso que nuestras propias sensaciones sean pensamientos. (Pradines, 1948 p. 8)
}

Pero adivinamos la réplica de los "cerebralistas": en efecto, según ellos, todo pasa por el centro; por tanto, este debe ser concebido como un cutáneo que se ha hipertrofiado y especializado, pero el psicofisiólogo lo autonomiza excesivamente y tiende a descuidar el resto.

¿La destrucción de la corteza misma del lóbulo occipital no entraña, por lo demás, la ceguera (definitiva)? Mejor aún, si la extirpación tiene que ver con uno de los dos lóbulos, la visión será abolida parcialmente: un tercio (externo) del ojo correspondiente y los otros dos tercios del ojo opuesto (una hemiopía lateral homónima). A decir verdad, el animal que ha sufrido esta lobotomía continuaría viendo, pero no reconocería ya lo que ve (por ejemplo, el perro ya no distingue a su amo); sería afectado de "ceguera psíquica". Sin embargo, según ciertos experimentadores, este animal lograría, por una parte, reconquistar poco a poco lo que ha perdido gracias a la ayuda de porciones corticales vecinas indemnes (el cerebro posee siempre esta especie de potencia regeneradora, lo que impide conclusiones abruptas o definitivas que la restauración desmiente). En el hombre esta deficiencia - la agnosia visual - tiene que ver con una enfermedad 
cerebral que golpearía ese mismo centro y que se saldaría con la imposibilidad de identificar lo que percibimos (la ceguera psíquica). Seguimos viendo, pero no sabemos lo que vemos, y especialmente las palabras escritas (o habladas: la ceguera verbal). Nadie se sorprenderá por esto: los términos cuentan no tanto por la materialidad (escrita o sonora), sino por el sentido que vehiculan; y es precisamente al cerebro al que le corresponde señalar e instaurar la comprehensión. Si seguimos percibiendo los rasgos del grafismo, ya no sabemos lo que indican.

En cuanto al segundo papel desempeñado por el cerebro, inseparable del primero (la recepción del mensaje que le es transmitido) — programático, de la reacción o la decisión-, dependería del lóbulo frontal. La experiencia sustractiva en el animal (una lobotomía) lo confirmaría. En lo que concierne al hombre, algunas circunstancias lo han privado de este centro, como el caso de ese obrero que fue víctima de un grave accidente de trabajo. En una cantera de construcción de una vía férrea, con el fin de provocar el estallido de una roca, tuvo que rellenar con pólvora un hueco con la ayuda de una barra de hierro. Ahora bien, recibió la carga explosiva en la cara; la barra atravesó el cráneo de abajo a arriba. Cuando murió, la autopsia permitió seguir el trayecto de esta barra que debía lesionar sobre todo la parte frontal del cráneo. Otros desafortunados padecieron el mismo drama, pero a todos les cayó una repentina apatía: la carencia evidente de toda iniciativa y la imposibilidad de coordinar los datos y de formar, por consiguiente, una réplica adaptada o el más mínimo plan (se ha perdido pues la regulación de la acción). Correlativamente, se enfrascan en los detalles, se esclavizan a un concreto que los absorbe. Por ejemplo, en el transcurso del examen se le pide a un antiguo herido resolver el problema siguiente: el hijo tiene quince años, el padre veinticinco años más y la madre cinco años menos que el padre. ¿Cuál es la edad combinada de los tres?

En su respuesta, [el enfermo inválido] sumó los tres números dados por el examinador $(15+25+5=40)$ y concluyó que esa era la edad combinada del padre, del hijo y idel espíritu santo! (un juego de palabras típicamente frontal). (Jeannerod, 1992, p. 245)

Con esta última fórmula asistimos a una simple asociación porque la tríada —el padre, la madre y el hijo- puede recordar la tríada religiosa vecina -el Padre, el Hijo y el Espíritu Santo-. Debemos notar, entonces, un relajamiento afectivo y un movimiento de humor y gusto por el retruécano; en resumen, cualquier cosa se junta con cualquiera otra. Se libera, así, una especie de emotividad eufórica y jovial.

¿No hemos aportado así la prueba de que la visión supone la integridad o la integralidad del lóbulo occipital, tanto como del frontal, en lo que concierne a la iniciativa consecutiva o incluso a la integración de los datos? 
Sin embargo, no suscribimos completamente esta conclusión. Para comenzar, resulta que "el descerebrado parcial" continúa percibiendo e incluso actuando; solo le falta lo que une esas operaciones. Subrayémoslo: estas resultan afectadas, reducidas a lo más elemental, pero un cierto fondo resiste o subsiste. Además, podríamos asistir a una relativa reapropiación de nuestro protolenguaje sensorial, gracias a un poder reconstructor (aunque limitado y tardío), que es preciso reconocerle al sistema nervioso.

Sobre todo nos preguntamos si esta patología, que es la ceguera psíquica o el no reconocimiento de lo que percibimos, puede compararse en gravedad con el deterioro que resulta de la situación inversa, es decir, aunque menos sangrante y menos destructiva (aparentemente), de la sola privación del juego sensoriomotor cuya importancia vital debemos admitir. En efecto, el experimentador coloca a un hombre voluntario y a un animal dentro de un recinto hermético: una especie de caja que asegura un completo "aislamiento" para que el viviente aprisionado escape a la menor solicitud venida de fuera. El voluntario es acostado en una cama, pero sus brazos son encajados en tubos de cartón resistente con el fin de evitar tanto la recepción como la autoestimulación táctiles. Los ojos solo registran la más débil de las luces debido a unas gafas apropiadas. Lo auditivo no funciona. Se alcanza la ausencia de toda "sensación". Ahora bien, pocos sujetos pueden soportar un tal régimen. Rápidamente surgen alucinaciones y, a la larga, se instala un estado de desarreglo. La policía habría utilizado este castigo tanto más en cuanto que los sujetos sometidos a este tratamiento no dejan de hundirse en la demencia hasta destruirse (un suicidio así les es imputado mientras que esta expresa lo intolerable; pero el poder puede lavarse las manos debido a que no ha participado directamente en esa muerte).

Por fuera de esta experimentación violenta creemos que el animal, en su medio natural, no puede vivir sin los beneficios del entorno que lo solicita. El gato, por ejemplo, exige caricias; cuando le faltan, las autoproduce frotándose en las patas de una silla o contra todo lo que encuentra en saliente; se asegura a sí mismo "su alimento táctil" que lo fortifica y le procura un real contentamiento (tal que lo acompaña de un ronroneo de satisfacción). Sin que lo perciba suficiente, el hombre también busca por todos los medios lo que lo vivifica. El yo experimenta la necesidad de un contacto directo con el suelo, lo que exalta "el tono muscular". Estar privado de él durante mucho tiempo debilita. Aquí, el afuera se pone a sostener y a animar el adentro; el sentir se vuelve indispensable.

Debido a todo esto, más allá de tomar en cuenta la sola "cerebralidad", debemos negarnos a separar los dos polos complementarios del sistema (el centro y su periferia, su tensión y su mutua dependencia). De esto se siguen numerosas consecuencias, como mínimo en el dominio de la medicina, por no decir en el 
de la terapéutica. Solo las podemos encarar para señalar los efectos, sin duda benéficos y "revitalizadores", de lo que preconizaban los griegos: los baños, las unciones, las fricciones y las caminadas. Pero tanto el biólogo como el antropólogo caen demasiado en la dualidad. Así, le dan más importancia a uno de los territorios de la relación, mientras que minimizan el otro (el periférico) que, sin embargo, es el más accesible.

Todo el tiempo el filósofo busca "el espíritu", pero este no es una cosa. No se acurruca aquí o allá, de donde habría que ir a sacarlo. Tampoco se inmiscuye en los pliegues del cerebro, como lo veremos mejor más adelante. Por el momento contamos con las relaciones que dinamizan. No excluimos entre ellas una participación sensorial que solo se limite a informarnos sobre lo que nos rodea, sino que, al mismo tiempo, nos haga seguros e incluso atrevidos.

Otra objeción u observación interrogativa: ¿No resultarían dos "impresiones" y, por tanto, una relativa discordancia del hecho de que todo órgano receptivo se desdobla? Sin embargo, nadie mejor que Bichat lo ha evidenciado: la vida animal se singulariza por la división en dos (la derecha y la izquierda), o incluso la asimetría por oposición a un visceral monolítico. Contamos con dos ojos, dos orejas, dos narices, dos manos y también una lengua que, a pesar de su unidad, comporta un surco mediano que marca la dicotomía. Un teórico como Gassendi ha pensado que solo un ojo debía actuar en la visión; en caso contrario, estaríamos provistos de dos imágenes diferentes (una horma de diplopía). En realidad, la razón de ser de esta escisión anatómica tiene que ver con que, gracias a la dualidad, podemos esperar un mejor y más completo resultado. Por ejemplo, los dos ojos se dirigen de tal manera que sus ejes ópticos convergen y se cruzan (la cima del ángulo óptico en cuestión se sitúa sobre el propio objeto; por ello, hay un solo "estímulo" con una indicación, además de la distancia o el tamaño, el relieve de lo que se capta). Por lo demás, una de las dos retinas ve partes que la otra no puede aprehender y viceversa; la superposición representa claramente el mismo objeto, pero visto de dos puntos ligeramente diferentes que no dejan de fusionarse. Acabamos de ampliar nuestro campo de observación. La estereoscopia lo evidencia: la ilusión del relieve nace del ligero desajuste entre las dos imágenes. ¿Y quién podría creer, en otro plano, que perdamos un cerebro derecho por el hecho de que no coincide con el izquierdo, mientras que esta distinción entre no puede más que darnos ventajas y permitir la división de las tareas?

Pero, para despachar a los teóricos que se oponen ásperamente a la naturaleza y al papel que conviene darle a la sensación (¿será preciso concebirla como una "casi nada" que el sujeto enriquece gracias a sus aprendizajes, experiencias, recuerdos e incluso su reflexión, o bien encubre en sí misma una 
cierta organización que la hace directamente significante?), fue previsto un procedimiento de evaluación decisivo (primero por Molyneux) y realizado poco después (Cheselden): se trata de tener en cuenta la intervención médicoquirúrgica que le devolvería súbitamente la escucha al sordo o la visión al ciego. Nos place anotar acá que una simple transformación corporal puntual va a permitir zanjar un grave problema metafísico, porque el ciego de nacimiento que ve de repente nos dirá si percibe e incluso lo que percibe; experimentamos una especie de situación adámica, esto es, la de un hombre que se abre al mundo por primera vez.

Por ejemplo, Condillac no ha dejado de reportarnos el caso de un sordomudo de nacimiento de veinticuatro años (la observación fue publicada en las memorias de la academia de ciencias, en el año de 1703) que, sin beneficiarse de una terapia restitutiva, se curó espontáneamente. "Le salió una especie de agua de la oreja izquierda y comenzó a escuchar perfectamente por los dos oídos". Inmediatamente, añade Condillac (1798a), "hábiles teólogos lo interrogaron sobre su estado pasado y sus principales preguntas giraron en torno a Dios, el alma, sobre la bondad o la malicia moral de las acciones" (p. 189) ${ }^{3}$. En efecto, se quería saber si este joven ya había encontrado en sí mismo las nociones esenciales (el innatismo) o si iba poco a poco a recibirlas, pero a fuerza de observar o incluso de experimentar (la tesis empíricogenética). Damos vueltas en torno a la misma pregunta: ¿el sentir arrastra todo el resto o lo esencial reside en nosotros?

Condillac está a favor de la comprensión plena de la sensación: su filosofía concibió e incluso popularizó "una estatua" que solo recibe un simple y único "olor de rosa" y, a partir de él, engendra el resto. Pero, para evitar el mentís, reconoce que no podemos esperar luz del relato y de las preguntas dirigidas al que comienza a escuchar. Esperamos mucho de ello, pero es necesario decantar. La pérdida del oído (o la ausencia de su funcionamiento desde el nacimiento) no solo nos ha cerrado a los ruidos, sino también al lenguaje (comunicarse con las manos, el lenguaje de los signos que fundó el abate Carlos Miguel de l’Épée, solo emergerá y se diseminará más tarde). El sordomudo - lo uno no va sin lo otro- ya no puede responder a las preguntas que se le formulan: "Se lo interrogó sobre su primer estado, pero él no recuerda como tampoco nosotros recordamos lo que nos ocurrió en la cuna" (Condillac, 1798a, p. 200), según el Ensayo $<$ Essai sur l'origine des connaissance humaines $>$. Y puesto que las palabras van a recibir la delegación de las cosas (harán presente lo que está ausente), nos ayudan a recordar. Participan en la elaboración de nuestras facultades. Carente

Entre paréntesis, Jean-Jacques Rousseau sacará otras conclusiones de estas situaciones: estos individuos que vuelven al ejercicio de sus sentidos echarían de menos su estado anterior (el silencio y la no-visión) más bien que abrir sus orejas y sus ojos a la vida social, llena de violencia, de combate y de malevolencia. 
de este medio indispensable, el desafortunado no puede abandonar la prisión de la inmediatez en la cual lo encierra su déficit auditivo.

Tomamos en consideración esta situación privilegiada (¿qué escuchamos la primera vez?), pero estamos en presencia de una doble invalidez; y como la una repercute en la otra, no sabríamos medir la primera, a pesar de que se recobre la sensación auditiva. Por lo demás, Condillac considera al sordomudo como próximo del muchacho aquel "de cerca de diez años que vivía entre los osos, en las florestas que confinan a Lituania y Rusia [fue capturado en 1694]. [...] Caminaba sobre sus pies y sobre sus manos, no tenía ningún lenguaje, producía sonidos que no se parecían en nada a los de un hombre" (Condillac, 1798a, p. 199). En este contexto, la ausencia de un lenguaje también es suficiente para dar cuenta de un retardo tal que impide "la humanización". No aprendemos nada de él; no podría revelarnos su estado: se le escapa o, si un día logra comunicarlo, solo nos dará un relato retrospectivo y, por tanto, arreglado.

¿El ciego de nacimiento - aquel al que el cirujano Cheselden va a quitarle las cataratas y liberarlo de su ceguera - va a ofrecernos la solución esperada? ¿No vamos a entrever gracias a él lo que nos suministra la sensación pura (la tabla rasa)?

Pero Condillac no ha dejado de oscilar en su respuesta. Por un lado, parece que el operado distingue sin dificultad "el cubo" de la "esfera" del mismo metal y del mismo tamaño; por otro lado, todo está borroso y desfigurado: "Un objeto de una pulgada puesto ante su ojo le parece tan grande como la casa" (Condillac, 1798b, p. 320). Si es verdad que ver no es mirar, entonces

¿cómo los ojos cuya visión no va más allá de la pupila podrían mirar? Pues finalmente, para mirar es necesario que sepan dirigirse a uno solo de los objetos que ven ¿Cómo incluso se dirigirán hacia alguna cosa? No es suficiente con ver para hacerse ideas, diría que tienen necesidad de aprender a mirar. (Condillac, 1798b, p. 280)

A tal punto flota Condillac que el propio Cheselden no le ayudará al filósofo a salir de su perplejidad: admite que el joven no logrará discernir ni identificar los objetos, pero nos asegura, al mismo tiempo, que "encontraba mucho más agradable los que eran regulares. A mí, esto me parece completamente contradictorio" (Condillac, 1798b, p. 321).

A decir verdad, Condillac (1798a), que le ha concedido mucho a la sensación (un sensacionismo antiinnatista porque no tendríamos ideas que no nos vengan de los sentidos, según el Ensayo), cuenta principalmente con el tacto para dar forma e instruir a los otros sentidos, incluida la vista. Pero se precisa tiempo para lograr esta formación. iPodría ser que el operado, en los primeros días, no viera nada o muy poco! La no visión de estos comienzos no invalida nuestra 
mirada. En suma, Condillac mantiene su tesis (que nosotros compartimos) pero la sustrae hábilmente del mentís de la experimentación (conviene dejar al operado el tiempo para ejercitar sus ojos y permitirle al tacto que los eduque).

Sobre esta cuestión preferimos seguir a Diderot (1749), más incisivo y menos impedido. Cuestiona sobre todo las pretendidas lecciones que creen poder extraer del "ciego de nacimiento y operado". Esta experiencia de la primera recepción de nuestro mundo se realiza entonces con el concurso del que puede comentarla, pues no podríamos contar con el niño. Cheselden (desde 1728) nos ofrece lo que no nos atrevemos a esperar: la sensación óptica tiene su estado primero, incluso en su ingenuidad, y un adulto que podrá instruirnos sobre ello. Diderot se va a dedicar esencialmente a salvar "la experiencia de Cheselden" de lo que la debilitaba y la falseaba mientras que nos prometía la luz; incluso terminaba evocándola para descalificar la vista. Diderot (1749) va a interpretarla de una forma completamente distinta:

Confieso que no entiendo lo que se espera de un hombre al que se le acaba de hacer una operación dolorosa sobre un órgano muy delicado, que el más ligero accidente molesta, y que engaña a menudo aquellos en que él está sano y que gozan desde hace tiempo de sus ventajas. (p. 126)

Diderot, el defensor de lo visual, va a cuestionar el desarrollo de una tal experimentación. En primer lugar, se cuestiona sobre cuál operado será preguntado: ¿el primer aparecido, un ignorante del envite o un sujeto informado del problema?

Si se quisiera dar alguna certidumbre a estos experimentos, sería necesario al menos que el sujeto fuese preparado durante largo tiempo, que se lo arrebatase y quizás que se lo convirtiera en filósofo; pero no es asunto de un momento producir un filósofo incluso cuando se lo es; ¿qué será cuando no se lo es? Y es mucho peor cuando se cree serlo. (Diderot, 1749, p. 127)

Iremos un poco más lejos: o bien el operado ignora todo sobre el problema y de lo que se espera - arriesga entonces responder de forma desconsiderada y poco tópica-, o bien está alertado e informado, pero solo hace que temamos muchos más sus prejuicios.

Diderot va a multiplicar las críticas y a enumerar todas las circunstancias o modificaciones aparentemente secundarias, por no decir mínimas, que vienen a pesar sobre los resultados: el menor cambio en el desenvolvimiento de esta observación modifica todo.

Por ejemplo, y este es el primer parámetro que hay que tener en cuenta: conviene colocar al operado en la oscuridad; el rayo de la menor luz le impedirá ver y nos apresuraremos a inferir su no visión del ojo. Además de las tinieblas, 
es necesario dejar transcurrir también un poco de tiempo, antes que precise lo que recibe,

todo el tiempo necesario para que los humores del ojo se dispongan convenientemente, a la córnea para que tome la convexidad requerida para la visión, a la niña de los ojos para ser susceptible de la dilatación y del retraimiento que le son propios, a los ligamentos de la retina, al cristalino para ejercitarse en los movimientos hacia delante y hacia atrás que se le sospechan, o a los músculos para que cumplan bien sus funciones, a los nervios ópticos para acostumbrarse a transmitir la sensación, al globo entero del ojo para prestarse a todas las disposiciones necesarias. (Diderot, 1749, p. 137)

Pero, además, y este es el segundo parámetro que sin duda ha sido mal o demasiado poco señalado, si se le presenta al antiguo ciego un cubo y una esfera, puede que no los distinga, pero si esos "objetos geométricos de forma" son coloreados - el cubo en negro y la esfera en rojo—, los discernirá sin dificultad.

Asimismo, si no se ha recurrido a "figuras elementales, como el cubo o la esfera, y se le propone al neovidente su bonete, su levantadora o sus zapatos", puede que no los vea. "¿Cree usted, señora, que si os mostrase hoy por primera vez un adorno, lograría adivinar en algún momento que se trata de un alfiler y que es un alfiler de cabeza?" (Diderot, 1749, p. 144). Es claro, entonces, que para comenzar esta prueba no debemos utilizar más que objetos bien desplegados, sin encabalgamientos de partes ni complicaciones morfológicas, como el bonete con las borlas y los perifollos que lleva. Es menester no desconcertar ni introducir cuestiones embarazosas.

Según la cualidad del operado, según lo que se le pida reconocer, todo se balancea del sí al no, pero esta experimentación es vista por Diderot como una trampa. Llega incluso a añadir que la conclusión dependerá también de quien la espera y la suscita. Por esto, precisa Diderot (1749),

sería necesario que este interrogatorio se hiciese en plena academia; o más bien, con el fin de no tener espectadores superfluos, solo invitar a esta asamblea a los que lo merecen por sus conocimientos filosóficos, anatómicos, etc. Las gentes más hábiles y los mejores espíritus no serían demasiado buenos para esto. (p. 128)

En suma, lo que está en juego en el célebre experimento cheseldiano es un cierto número de variables y de tal género que, a la menor transformación de una de ellas, el resultado cambia. No podemos concluir nada porque todo depende del que interroga, del interrogado y, finalmente, de lo que se muestra con miras al reconocimiento ${ }^{4}$.

4 Todos los argumentos son buenos; no seamos demasiado exigentes. Por ejemplo, tomamos de Cabanis (1802) esta anotación (convergente): "Las aves de la gran familia de las gallináceas caminan tan pronto salen del cascarón. Se las ve correr diligentemente tras el grano y picotearlo sin cometer ningún error de óptica, lo que prueba que no solamente saben servirse de los músculos de sus piernas, sino que tienen un sentimiento 
Diderot iría también a refutar la teoría de un ojo que debía ser educado por el tacto (la tesis de Condillac), lo que tiende hábilmente a desconsiderar uno de nuestros receptores sensibles. iPero no tratéis - parece afirmar Diderot a través de su réplica-de engrandecer el uno para mejor disminuir el otro! Finalmente, por algún lado, Condillac se ha reunido con el campo de los antisensacionistas. $\mathrm{Al}$ respecto, Diderot (1749) afirma: "Yo me preguntaría si es el tacto el que le enseña al ojo a distinguir los colores. No pienso que se le conceda al tacto un privilegio tan extraordinario" (p. 137).

Diderot acepta claramente que uno de nuestros órganos sensibles puede suplantar a cualquier otro, aquí o allá, pero con la condición de que lo inverso sea posible: la vista se pone a guiar o a informar nuestro tacto impedido. "Los servicios son recíprocos; y en los que tienen la vista más fina que el tacto, es el primero de estos sentidos el que instruye al otro de la existencia de objetos y de modificaciones que le escaparían por su pequeñez" (Diderot, 1749, p. 136). Así, de un cabo al otro de su análisis, Diderot ha logrado descartar las trampas.

Habíamos creído en una real experimentación psicológica y metafísica que habría de ofrecernos la "visión adánica" y zanjar fácilmente la cuestión pendiente, a saber: ¿cuando vemos por primera vez, vemos cuando abrimos los ojos? Molyneux había deseado con todos sus anhelos lo que Cheselden, el cirujano, habría de realizar: devolver la vista a un ciego de nacimiento.

Pero los filósofos habrían de concluir rápidamente que el operado no veía nada; se apoderan de este resultado para desarrollar y consolidar la teoría dominante, esto es, el antisensacionismo. Si Diderot reconoce que seguramente aprendemos a ver mejor gracias al uso, sigue siendo cierto que vemos, pero con la condición de que ese delicado ejercicio no sea impedido, como lo ha sido anteriormente (sin que se den cuenta los observadores). En efecto, todo cambia según la presencia de tal o cual experimentador, si los objetos son fáciles o no de identificar y según la docilidad del que se interroga y al que quizás se le inspira la respuesta.

Pero los fisiólogos y los médicos van a exagerar sobre los filósofos: creen tener que valorizar el mecanismo sensitivo; le confieren tales capacidades que lo esencial del sentir se encontraría en él. El nervio transmisor ya no se limita a la difusión del mensaje (para conducirlo al cerebro), sino que, en el límite, lo conforma y lo elabora. Le es suficiente al fisiólogo con notar que un mismo excitante -una débil descarga eléctrica- da efectos diferentes (luz, sonido, olor, etc.) según el órgano sensorial que habría sido tocado. Asimismo, una misma irritación de

preciso de cada uno de sus movimientos, que saben igualmente servirse bien de sus ojos y que juzgan con exactitud distancias. Este fenómeno trivial, que se observa cotidianamente en los corrales, es bien capaz de hacer soñar a los verdaderos pensadores" (p. 125). 
naturaleza mecánica produce aquí una imagen luminosa y en otra parte una especie de zumbido. Inversamente, según la teoría de Johannes Müller, expuesta en su Tratado de fisiología de 1840 (la teoría específica de los sentidos), causas externas desemejantes provocan el mismo efecto según el órgano concernido. Por este hecho, el estímulo pierde su importancia (objetiva) porque nuestros aparatos transforman lo que reciben (y lo mismo fábrica de lo otro y recíprocamente).

Johannes Müller (1840) ha trascrito los nuevos principios de su fisiología nerviosa bajo forma de proposiciones que definen ellas mismas un cuerpo doctrinal singularmente consistente o constituido:

\footnotetext{
"La misma causa interna suscita, en diferentes sentidos, sensaciones diferentes, dependiendo de la naturaleza del sentido excitado" (proposición II); "Con una misma causa externa se produce lo mismo" (proposición III); "Las sensaciones propias de cada nervio sensorial pueden ser engendradas por diferentes causas, externas o internas" (proposición IV).
}

Johannes Müller ha definido la sensación como una modificación del organismo y no como lo que podría informarnos de una cualidad de nuestro mundo. No suscribimos una conclusión así en tanto que discutimos la naturaleza de las pruebas encargadas de sostenerla o imponerla. En efecto, una verdadera sensación se caracteriza esencialmente por la distancia entre el estímulo y el receptor; nos entrega incluso una anticipación de lo que ocurrirá según si nos aproximamos o nos alejamos. Incluso cuando creemos observar una especie de contacto, entrevemos el medio disponible para evitar la fusión o el exceso de proximidad, aunque el tiempo del encuentro (sujeto/objeto) no dure y la mano apenas roce. Los trabajos de Johannes Müller se invalidan por sí mismos; se sitúan por fuera del campo que cree estudiar o explorar. No debemos esperar nada de lo que consiste en dar golpes, incluso suaves, o en electrizar, aunque débilmente, golpeando un aparato tan sensible que solo puede recoger lo infrareflexógeno (matices, reflejos, cualidades).

Lo que encara el físico de la sensorialidad contacta las tesis del idealismo filosófico, que generalmente es hostil. En este contexto, cree mostrar que el nervio (y ya no el pensamiento o el juicio) fabrica lo que experimentamos, puesto que otros excitantes no son reconocidos en su originalidad. El nervio les impondría "el resultado". Mientras que nuestro cuerpo ha logrado abrirse al afuera, la fisiología de la energía específica de los nervios nos aprisiona en nosotros mismos; no sabríamos encontrar concepción más empobrecedora y más reductora.

Y cuánto nos alegramos por leer esta anotación deslumbradora y pasablemente correctora en un filósofo del siglo XIX:

Para ocuparse de fisiología honestamente, es preciso que los órganos de los sentidos no sean considerados como fenómenos en el sentido de la filosofía idealista. 
De lo contrario no podrían ser causas. El sensualismo sería, por lo menos, considerado como hipótesis reguladora, para no decir que como principio heurístico. iCómo! ¿Pues no hay quien pretende que el mundo exterior es obra de nuestros órganos? Pero entonces nuestro cuerpo, que forma parte del mundo exterior, ¿sería la obra de nuestros órganos? Por consiguiente inuestros órganos serían la obra de nuestros órganos! (Nietzsche, 1965, p. 469)

Se plantea una cuestión vecina, pero también facticia: resulta que nuestros fisiólogos han querido ver directamente, de alguna manera, cómo ve el ojo. Muchas preparaciones han fabricado especies de "mirada de la mirada": han mostrado que los objetos iluminados, colocados delante del ojo, imprimían en el fondo de este órgano-pantalla imágenes fáciles de observar, pero todos los datos recibidos no han dejado de ser invertidos (lo bajo arriba). ¿Cómo realizamos el enderezamiento? ¿Dónde, sobre cuáles bases y con cuáles ayudas? ¿En qué momento? Magendie debía arrastrarnos a observar de cerca esta región posterior del ojo en los animales albinos y después de haber separado todos los tejidos adherentes a la esclerótica. La duda ya no está permitida: el cuadro retiniano sorprende por sus dimensiones reducidas (la miniaturización) y sobre todo por su claridad; sin embargo, las partes inferiores de la escena ocupan la región superior e inversamente. Lo que se encuentra a la derecha está situado a la izquierda y recíprocamente. Cuando el fisiólogo pone un cuerpo ante este ojo, el movimiento, en la imagen, parece inverso al del objeto. ¿Cómo pasar, entonces, de un tal cuadro al que retenemos?

Los fisiólogos han aprovechado esta ocasión para valorizar el tacto y encargarlo de la función correctora:

El gran maestro que el alma ha seguido en esta reforma es el sentimiento del tacto. Esta sola sensación es el juez competente, el juez soberano de la situación de los cuerpos; es este maestro el que primero nos ha dicho que caminamos de pie y que, sobre esta primera regla, nos ha dado la verdadera idea de la situación de los otros cuerpos. (Lecat, 1767, p. 417)

Con la explicación de la sensación que hemos dado, la pregunta que perturba al psicofisiólogo — ¿cómo se opera el enderezamiento? — pierde su sentido y no nos concierne. En efecto, la sensación no se identifica con un calco o un pictograma que nos ofrecería, bajo una forma reducida, lo que vemos. No busquemos, con el fisiólogo - víctima de su hiperrealismo - una similitud objetiva entre la "escena exterior" y su pretendido reflejo depositado en nosotros, y como si el mundo viniese a reflejarse en nuestras células (los conos y los bastoncitos). Somos tocados, no por una "imagen", sino por una información suficiente para que evitemos el peligro o para que tomemos ventajas.

La campana que suena, mutatis mutandis, previene al señor de la casa de la llegada de un visitante, pero lo que escucha no mantiene ningún lazo (mi- 
mético) con el que se anuncia (aunque se hayan podido adoptar convenciones entre los dos protagonistas, de tal manera que los sonidos de la campana sean suficientes para indicar al que la acciona).

Lo admitimos: alguna semejanza subsiste, sin embargo, entre el cuadro retiniano y lo que él reproduce (el exterior), aunque lo ofrezca al revés a causa de la inversión. El dato ocular no ha roto enteramente con lo que permite ver, pero allí no reside su papel ni mucho menos su estatuto: puede tomarse libertades con respecto a su referente. Nos muestra un poco de él y bastante como para que podamos reconocerlo inmediatamente. Sin embargo, lo esencial no consiste en la fidelidad, sino en la utilidad: iesto es lo que se encuentra ante ti! Por lo demás, algunos objetos, ya sean vistos a la derecha o a la izquierda o incluso al revés, no son modificados por eso (el cubo, por ejemplo); además, una "señal", cualquiera sea su posición, asegura su función vital y preventiva. No somos retenidos ni por su emplazamiento ni por su orientación. Solo cuenta la información: el significante, en el cual el mensaje se inscribe, lo deforma a veces y llega hasta velarlo, pero sabemos leer el significado sin que sea contaminado por lo que lo lleva (se puede presentar cabeza abajo).

Pero el médico llega pronto a ayudar al fisiólogo: va a esculcar en algunas observaciones clínicas elementales con qué "desencallar" el antisensacionismo del biólogo, al que acusamos de exceso de cerebralismo que, por lo demás, comparte con el psicólogo y el filósofo. iCuántos pacientes han sido engañados por lo que creían experimentar! En este caso se trata, por lo demás, no tanto de un "ver mal", sino de un "ver" lo que no existe: una cuasialucinación.

De esta forma, ha sido ampliamente explotada la ilusión del "miembro fantasma" que Descartes (1642) ya había destacado en su Sexta meditación metafísica. Allí mismo, avecindando con el comportamiento tan extraño del hidrópico, un enfermo engañado por una intensa sed que aumentaría su mal prueba la nocividad de una información recogida por uno de nuestros sentidos ${ }^{5}$.

Descartes, aunque "antisensacionista" (ialejemos lo que nos imponen nuestros sentidos que a tal punto nos engañan!), debía explicar y, en suma, anular estos errores corporales y esta fisiología falsa porque en este caso no podemos evitar tales desarreglos: la sed que quema el gaznate y el dolor intenso en una pierna (amputada). Acá no es nuestro juicio el que está cuestionado, sino la cualidad del Creador de nuestros dispositivos de alerta sensorial. Dios se encuentra

Para nosotros se trata de una diabetes llamada insípida: el enfermo bebe cantidades inimaginables que elimina inmediatamente. No puede calmar una sed invencible a pesar de los diez litros absorbidos en una jornada. Un enfermo -el paciente llamado Pidoux, del que los tratados reportan el caso- habría bebido cuarenta y cinco litros en veinticuatro horas. Y eliminó otro tanto. Estos enfermos beben cualquier cosa con tal de apaciguar su sed. 
directamente incriminado. Descartes busca precisamente no validar las impresiones falsas, sino declarar inocente a Dios de semejante desorden.

Nos encanta que una cuestión psicofisiológica de repente se haya transformado en una interrogación teológico-metafísica, mientras que la sensación ha estado frecuentemente relegada a lo más bajo iy no abandonaba el suelo de la fisiología!

Pero para dar cuenta del dolor del "miembro fantasma" (después de la amputación), Descartes utilizará una comparación mecánica:

En la cuerda $A B C D$, completamente tendida, si llegamos a tirar y a remover la última parte $\mathrm{D}$, la primera $\mathrm{A}$ no será movida de manera distinta a lo que lo podría también ser si se tirara de una de las partes medias B o C, y que la última D permaneciera sin embargo inmóvil.

En suma, cuando se tira de una de las extremidades de una cuerda, el otro extremo también será sacudido (gracias a una transmisión rápida, breve, infaltable). ¿Pero por qué no se sufre en la rodilla, allí donde muy frecuentemente se detiene el miembro restante?

Creemos poder explicar la extrañeza del sufrimiento en un pie que ha sido cortado. Primero, el nervio se limita a comunicar una especie de estimulación que lo ha golpeado; ¿por qué conferirle, además, el cuidado de precisarnos el lugar concernido? iNo transformemos un dispositivo de viva información en un aparato localizador! Si entrase en tal juego, seríamos detenidos o alertados por numerosos "detalles" (topográficos e inútiles) que podrían extraviarnos. Y acá, donde muchos ven un "error", nosotros creemos discernir una verdadera ventaja: en efecto, conviene referirlo todo a la extremidad (cualquiera sea), puesto que es la única que se encuentra en peligro. Hemos subrayado suficientemente la importancia vital de lo periférico, allá donde reside lo esencial de la organicidad, como para poder subrayar con satisfacción que el cuerpo lo privilegia directamente. ¿Pero por qué hay dolor sin objeto ni indicación, puesto que concierne a un "miembro que ya no existe"?

René Leriche (1940), en su obra sobre La cirugía del dolor, nos ha enseñado que en el lugar de la resección del nervio había riesgo de que se desarrollara un "neuroglioma", esto es, un brote en yemas celular que implicaría la irritación. Comprendemos entonces la existencia de esta incesante instancia dolorosa, a la cual será posible poner fin.

Pero esta ilusión del "miembro fantasma" nos conduce a una discusión más amplia, a la que ella convoca y que por lo demás cuestiona todo: ¿no debemos reconocer a la vez, como ella lo exige, "una posible sensación de dolor" como la que nos viene de nuestros órganos internos (la cenestesia)? ¿No es evidente que experimentamos 
en nosotros mismos, a propósito de nuestras vísceras, por no decir en la pierna (el miembro fantasma), impresiones que se parecen a lo que recolectamos en los lugares especializados como el ojo y el oído? (Leriche, 1940)

Sin embargo, vamos a discutir esta concepción. Pero es preciso que comencemos por escuchar los argumentos de sus defensores.

Cabanis (1802) se dedicó a convencernos de que los órganos de la digestión y los de la generación despiertan en nosotros imágenes y sobre todo representaciones, oscuras y vagas, pero ciertas, que establecen la relación entre el abdomen y el centro. Cabanis reconoce, en este sentido, la existencia de dos fuentes susceptibles de alertarnos y de informarnos: la externa, que se impone en el estado de vigilia y reprime la otra; y la interna, que en la noche y en el momento del sueño toma su desquite y nos inunda con su propia vida. Condillac solo reflexionó sobre la primera, mientras desconoció la segunda.

Las ideas y las determinaciones morales no dependen únicamente de las sensaciones, es decir, de las impresiones recibidas por los órganos de los sentidos, sino también de las impresiones resultantes de las funciones de muchos órganos internos que contribuyen más o menos a ellas y, en algunos casos, parecen ser las únicas que las producen. (Cabanis, 1802, p. 113)

Sin tregua Cabanis (1802) ha insistido:

Las unas [las impresiones] le vienen de los objetos exteriores, las otras, recibidas en los órganos internos son el producto de las diversas funciones vitales. [El individuo] tiene casi siempre la conciencia de las unas, ignora las otras, no tiene al menos de ello un sentimiento distinto. (p. 103)

Según Cabanis (1802), importa tener en cuenta nuestros sueños que dependen de la agitación interna y del aspecto sensitivo-cerebral ("[e]l alma está agitada de afecciones evidentemente producidas las unas y las otras sin la participación actual de los sentidos exteriores" (p. 111)). Por ejemplo, un sujeto se ve transportado de urgencia a una clínica para una intervención quirúrgica y se despierta en medio de esta pesadilla. Pero, al mes siguiente, va a tener que vivir lo que entrevió en las imágenes oníricas (el famoso sueño de porvenir). ¿Por qué y cómo? En su sueño ha podido experimentar un ligero malestar debido a una ralentización de la circulación de la sangre que debilita su corazón, lo que ha provocado la secuencia del sueño. En suma, tuvo una impresión tan débil que no podía registrarla ese día. La realidad vendrá pronto a confirmar la existencia de ese desorden incipiens, entreapercibido de manera confusa. Vemos acá una prueba a favor de una sorda comunicación entre lo visceral y lo cerebral (la parte en dificultad no puede repercutir sobre el todo). Incluso se trataría, según algunos, de una sensación de sí por sí mismo. De manera concomitante, para que se pueda presentar esta autoinformación, debe ser abolida la relación con el afuera. 
Beaunis, por su lado, consagrará una obra que precisará las proezas de la cenestesia (las sensaciones internas): descubre la importancia de esta en los animales donde ella es susceptible de guiarlos. Evidencia numerosas sensaciones de tipo desconocido. Gracias a estas, las ligeras modificaciones les permiten representarse mejor su propio medio sin aparato receptor apropiado o conocido. Por ejemplo, el perro o el gato pueden reencontrar su morada o el territorio de donde han sido alejados. Aunque hayan sido transportados en canastillas cerradas, a largas distancias, ellos regresan a su lugar de origen. Algunos han creído poder explicar esta proeza a partir de un olfato desarrollado (como si el animal, a la manera de Pulgarcito, que sembraba de guijarros su camino, se limitase a seguir "su antigua huella", la de una ida que dibujara también el regreso). Pero la mayor parte de los psicofisiólogos han admitido más bien una sensibilidad espaciomagnética (interna) que guiaría seguramente a los extraviados. ¿Por qué descartar el olor como señal? Pues porque el viento lo desplaza o porque él no permanece durante mucho tiempo, o también porque el animal va a reencontrar a su amo gracias a un camino más rápido que el que se había seguido.

Nos oponemos a esta doble conclusión - la de una posible sensación odorífica, así como a la de una verdadera información cenestésica- por razones a la vez lógico epistemológicas y experimentales.

¿Podemos ser al mismo tiempo sujeto y objeto de una apercepción? ¿Puedo verdaderamente experimentar en mí mismo un estado propio que me sería exterior? No dudamos de que podemos experimentar una especie de molestia (de malestar) debida, sin duda, a tirones, compresiones e, incluso, a ardores. Pero a este conjunto le falta la designación clara de un verdadero estímulo que permita definirla como "una sensación".

No olvidemos sobre todo que el dolor que se siente no corresponde ya al territorio donde parece enraizarse; no solamente es obtuso, errático, sino sobre todo desfasado, puesto que no indica el lugar y mucho menos la causa que lo suscita. Por ejemplo, el sufrimiento cardíaco se repercute en el brazo, el antebrazo e, incluso, la mano, que están bastante lejos de la región concernida; también puede sentirse a lo largo del esternón. Y el clínico sobresaldrá leyendo estos "síntomas" (sinalgias) y pondrá mucho cuidado en no tomarlos a la letra. El que señala su corazón o su riñón o su hígado como los "lugares del dolor" no sufre ni del uno ni de los otros. Se conocen fenómenos desconcertantes de aloquiria, es decir, que una anomalía y una algia en la mano derecha se siente también en la izquierda.

Para este dolor que viaja no vemos el "tejido receptor y diferenciado" que lo captaría, los nervios que lo conducirían ni los centros independientes que lo interpretarían. Peor aún, no se presenta en los órganos profundos, puesto que 
el estómago, el propio cerebro, los pulmones y el hígado son todos insensibles. Todos soportan ser traspasados o cortados. Más grave aún - y por esto nos regocijamos- el disfuncionamiento visceral no dejará de exteriorizarse y proyectarse, tarde o temprano, en la pantalla cutánea (la única, como lo sabemos, que expresa y expone nuestra reactividad).

No olvidemos que el dolor no tiene que ver con un excitante específico, porque cualquier estímulo puede volverse insoportable desde que alcance una cierta intensidad. Después de una "sensación sin la sombra de un dolor" puede venir una sensación que rodee las premisas del dolor y, finalmente, un dolor que no tenga nada representativo. M. Pradines (1943) ha insistido en esto:

Cuando la sensación se desarrolla a lo largo de una escala de intensidades crecientes, no se transforma en dolor en un grado determinado; simplemente, en ese grado, se vuelve imposible. De esta forma, cuando la cuerda que se hace vibrar es sometida a una tracción cada vez más fuerte, el sonido se vuelve cada vez más agudo, hasta que al término la cuerda se rompe, pero la ruptura de la cuerda no es el término de las alturas del sonido, ella es solamente el límite y la destrucción de las condiciones mismas del sonido. De manera semejante, el dolor pone fin a la actividad sensorial más bien que prolongarla. (p. 349)

¿Por qué este dolor? Lo comprendemos como el precio que tiene que pagar un individuo que se ha abierto a "lo infrareflexógeno", a rozamientos tan débiles que no podemos experimentar por sí mismos, sino solamente como la anticipación o el testimonio de lo lejano (de ahí la obligación de la distancia entre lo que nos toca y lo que él significa).

Nos rehusamos a ligar el dolor con el sistema sensorial que lo difiere, tanto a causa del alejamiento de lo que nos alerta como de su extrema minimalidad, mientras que el dolor se encuentra en nosotros, nos habita y va hacia la exacerbación. ¿Pero por qué algunos los aproximan? Porque así trabajan hábilmente (en tanto que indirectamente) en debilitar la sensación y fundirla en lo corporal, del que aquella se ha desprendido parcialmente (sin suprimirlo). Sin embargo, el sentir nos abre al exterior, mientras que el sufrimiento nos repliega sobre nosotros mismos, nos hunde y añade un mal al mal, pues le quitamos toda utilidad; no sirve para anunciar lo que nos amenaza, sino que se limita a intensificarlo. Igualmente, la cenestesia pertenece al mismo grupo: no podríamos hacerla equivalente a lo que nos da la vista o el oído, gracias a los cuales accedemos a la exterioridad. La gloria de la sensación consiste en su doble polaridad: por un lado, toca nuestro cuerpo en sus territorios especializados, donde puede recibir las impresiones más débiles (no podrá ya luego registrar las violentas, excepto que pague el precio del dolor); por otro lado, como lo hemos subrayado, este "ligero adentro" cuasi insensible, remite necesariamente a un afuera y nos informa sobre él. En desquite, experimentar en sí mismo y sobre sí mismo una 
especie de afectividad confusa, imprecisa, no localizada verdaderamente, e irradiante no llena la condición requerida para equivaler a una sensación, puesto que el adentro incierto no está vinculado (o lo está mal) a lo que lo condiciona; será preciso un lector competente, el que conoce el código de las expresiones y de los desplazamientos, para interpretar la escena cenestésica.

Y no hemos terminado con nuestra defensa de la sensación, que ha sido desacreditada y combatida. Por regla general los filósofos la han desconsiderado: el reproche principal consiste en que ella nos engañaría o, al menos, solo nos daría informaciones particularmente pobres o, más frecuentemente, falsas. Su doble pertenencia, que señalamos con el fin de definirla, es suficiente para desvalorizarla, pues con ella solo alcanzamos el exterior a través del interior, un mixto peligroso y confuso. Esto quiere decir que lo que aprehendemos corresponde a lo que experimentamos y, por esto mismo, percibir no podría escapar a lo personal. Debido a este doble registro nos vamos a perder sobre los dos tableros: primero, en razón de la dominación del estímulo, pronto no sabremos lo que ocurre en nosotros. Y en cuanto al medio que nos rodea, solo será captado en tanto coloreado por nuestra propia subjetividad. Por ejemplo, el color rojo que vemos no indica una propiedad de la cosa, sino que resulta de innumerables vibraciones de las que no tenemos la menor idea. Bergson (1963) no ha dejado de comentar este desfase:

En el espacio de un segundo, la luz roja — la que tiene longitud de onda más grande y cuyas vibraciones son por consiguiente las menos frecuentes-realiza 400 trillones de vibraciones sucesivas... Mi percepción me es claramente interior puesto que contrae en un momento único de mi duración lo que se repartiría, de suyo, en un número incalculable de momentos. (pp. 391-392, 394).

Pero allí donde algunos disciernen un estatuto particularmente desventajoso - la mezcla de los géneros, la confusión del universo con lo que experimenta nuestro cuerpo y el uno que emerge solamente a través del otro- creemos reconocer una situación eminente y deseable, porque retiramos de este mundo conocimientos directos y rápidos que nos ayudan y que nos sirven; somos inmediatamente provistos de referencias. Un saber ilimitado y estrictamente objetivo nos echaría a perder y nos impediría vivir.

Seguramente rebasaremos el estadio de lo perceptivo, pero, antes de entrar en la tecnosfera (reconstituiremos nuestro medio), ganamos al asegurarnos de lo que es.

Pero nos proponemos principalmente mostrar que la sensación, nuestra guía, no nos engaña, contrariamente a lo que sostienen tanto el escéptico (el negador de toda evidencia) como el dogmático (que rechaza un tal testimonio). N osotros nos inspiramos de nuevo en Descartes, poco sospechoso de adhesión 
a la filosofía sensualista (o sensacionista), vector y sostén de la exteriología, a la que en parte ha combatido.

Primer reproche: se acusa a la sensación de sitiarnos con anuncios bastante toscos e incluso truncados, capaces de perdernos. Solo nos entrega apercepciones sumarias. Por ejemplo, anota Descartes: "mi naturaleza resulta engañarme directamente, como, por ejemplo: cuanto el agradable sabor de algún manjar emponzoñado me incita a tomar el veneno oculto, y, por consiguiente, me engaña".

Pero si el gusto analizara las sustancias alimenticias y supiera detectar en ellas los principios tóxicos, no podríamos nutrirnos, sino que sería preciso esperar el resultado de innumerables evaluaciones. Cada una de ellas exige complicadas manipulaciones porque en el menor pedazo, icuántos elementos diversos conviene distinguir! ¿Cómo saber, incluso, que un cuerpo metido en otro podría nutrirnos? Antes de responder sería necesario experimentar y reparar en un individuo indemne la peligrosidad del producto del que se sospecha. Y no lo lograríamos. Claude Bernard ha mencionado que el menor cambio (la dosis, el ritmo de la toma, la vía de introducción, etc.) anula o intensifica la nocividad. Pharmakon, en griego, significa tanto el bienhechor como el malhechor, a tal punto que se confunde el uno con el otro. La misma sustancia que cura (es activa y debe serlo) puede arrastrarnos a la perdición puesto que poca cosa es suficiente para operar la inversión.

Descartes sostiene:

Nada puedo inferir de esto [de la carne envenenada] sino que mi naturaleza no conoce entera y universalmente todas las cosas; y no hay en ello de que sorprenderse puesto que el hombre, al ser de naturaleza finita, solo puede tener un conocimiento de una perfección limitada.

Nosotros sacamos otra lección: estaríamos baldados por ese saber que Descartes parece valorizar (debido a su absolutez y a su universalidad), puesto que nos habríamos transformado en un laboratorio a la búsqueda interminable del menor ingrediente; incluso no sabríamos zanjar en lo que concierne a lo venenoso.

Segundo error atribuido a la sensación y que la demuele: Descartes vuelve al "caso del sueño" en el cual vemos y escuchamos lo inexistente (los fantasmas). ¿No es esta la prueba de que el sentir no me pone en relación directa y verdadera con lo que lo produce?

Todo lo que he creído sentir estando despierto, puedo también creer que lo siento estando dormido; y como no creo que las cosas que me parece sentir, cuando duermo, procedan de objetos que estén fuera de mí, no veía porque habría de dar más crédito a las que me parece sentir cuando estoy despierto. (Descartes, 1642). 
El propio Descartes anula la objeción: según él, a la escenografía onírica le falta lo que podría hacerla creíble, especialmente la continuidad, una cierta coherencia y una verdadera información; estamos en presencia de lo descosido, de lo burlesco y de lo inverosímil.

Debo rechazar todas las dudas, particularmente esta incertidumbre tan general en lo tocante al sueño, que no podía distinguir de la vigilia; pues ahora advierto una notabilísima diferencia en que, nuestra memoria no puede nunca ligar y juntar nuestros sueños unos con otros, ni con el curso de la vida, como sí acostumbra reunir las cosas que nos acaecen estando despiertos.

Finalmente, con estos espectros y otros fantasmas que creemos apercibir en la noche del sueño, recaemos en la cenestesia que inspira estas imágenes, no solamente desordenadas y flojas, sino siempre excesivas y violentas. Por el contrario, en la verdadera sensación el afuera se impone y se deja ver (serenamente). Falta en la pesadilla el enlace entre un desfile bizarro y la realidad, mientras que lo contrario se pasa con la luz del día. Las dos situaciones difieren del pro al contra y una no puede servir para desconsiderar la otra.

Pero abandonamos a Descartes porque los tratados de psicología evocan numerosas situaciones en las que somos traicionados por lo que vemos, como aquella torre redonda que de lejos parece cuadrada y sobre todo el cubo que creemos notar cuando en realidad solo recibimos de él algunas aristas, una o algunas caras desiguales. Debemos reconstruir este dato al punto en que la figura del cubo trasciende la perspectiva a través de la que se nos aparece. La verdad o la realidad del sentir no resulta acá de un visual que deforma, sino de nuestro juicio llamado a reordenar las líneas.

No ocultamos nuestro desacuerdo con respecto a esta tesis que, sin embargo, es canónica y compartida; para nosotros la parte puede expresar objetivamente el todo y de alguna manera contenerlo. Por lo demás, no existe nada que nos sea propuesto por entero; lo de abajo o lo de atrás de cualquier cosa se nos escapa y lo de adelante es suficiente para representárselo. ¿No se revelan indispensables, en este contexto, el saber, la experiencia, el recuerdo y los hábitos? Aquí apenas recurrimos. Es verdad que la memoria puede intervenir, nunca hemos negado su papel; pero pensamos que si ella es solicitada y funciona es porque ha sido evocada por lo ya constituido y lo organizado. ¿En caso contrario, qué lección del pasado sería solicitada? Completamos el "documento sensible" y esta es la prueba que encerraba ya los comienzos (significativos).

En resumen, no somos engañados en el caso del veneno con el sueño ni con sus extravagancias, tampoco por la figura truncada o aparentemente quebrada. El sentir siempre nos dice lo mejor y lo que corresponde a lo verdadero, no la 
verdad absoluta, que sería ruinosa, sino lo que le sirve a nuestro ser y lo aclara. Esto verdadero sabe tener en cuenta lo objetivo y lo subjetivo.

Sin embargo, para volver sobre una anotación crítica del opositor a estas afirmaciones: lo que a uno le parece agradable y dulce al otro le parece penoso y amargo. Dos pesos, dos medidas; ¿cómo fiarse de lo que nuestros receptores dicen? Precisamente, los cuerpos diferentes y el cuerpo mismo se modifican sordamente. El sentir coincide con estos diferentes estados. Sacamos la prueba de una sutil adaptación a los cambios: la de su fidelidad con respecto a lo que nos importa. Lejos de ver acá signos de labilidad o de inconstancia, reconocemos una seguridad metrográfica.

Llegamos así a algunas conclusiones generales que implican nuestro examen de la sensación y sobre todo su rehabilitación. Ante todo, nos distanciamos del fisiólogo porque le ha concedido demasiado al cerebro (el cerebralismo). No porque cuente poco, ini más faltaba!, sino porque este solo no equivale a la totalidad de la operación, ya sea que se trate de la recepción del mensaje o de la reacción que no deja de venir luego. En realidad, el encéfalo aloja esencialmente los circuitos neuronales (lo mnemónico, las adquisiciones), y sus células conectadas unas con otras sirven principalmente para conservar los recuerdos y, por tanto, para permitir una mejor comprehensión de la situación, así como para orientar la respuesta. El influjo nervioso circula a lo largo de circuitos complejos y arborescentes: A evoca B, B conduce a $\mathrm{C}$ y $\mathrm{C}$ despierta a $\mathrm{D}$ antes de volver sobre A. Lo hemos mencionado: tal o cual dato será censurado, sin duda, en razón del sistema educativo que forja las prohibiciones. Por el contrario, si evolucionamos en lo permitido, el llamado lanzado por nosotros equivaldrá al enriquecimiento de lo que habrá sido recibido, esto es, si haces esto resultará aquello. Podrá incluso ser encarada una situación nueva: ¿qué ocurrirá si...? No minimizamos el peso de los recuerdos que la caja craneana contiene, pero no deja de existir la pregunta espinosa, muchas veces entrevista: ¿de dónde viene la sacudida que plantea el problema a la llegada?

La sensación originaria y primera mantiene ese papel, pues si el sentido no se encuentra al comienzo, nunca jamás tomará su sitio dentro del sistema neuronal. ¿Entonces, cómo será avisado este, por no decir inquietado? Por otra parte, si el estímulo solo interviene como un simple choque, mecánicamente no podría transportar con él la información. Pero tampoco vemos cómo un simple impulso (ciego) podría, de ahora en adelante, "tocar" el psiquismo o al menos el conjunto celular central.

Recogemos aquellas bellas anotaciones de Bergson, aunque nuestras concepciones finales difieran claramente: en efecto, el filósofo tiende a debilitar lo más posible "la cerebralidad" (en esto se separa del fisiólogo) porque el 
recuerdo no la habita, sino que se sitúa en lo inmaterial (el psiquismo puro). De la misma manera, Bergson disminuye también "la sensorialidad" en la medida en que la desprende de sus determinantes. Según Bergson, ella habría sido excesivamente definida con la ayuda de la causa (exterior) que la alteraría. $\mathrm{Si}$, por ejemplo, multiplico por dos la presión, arriesgamos con creer que una "impresión" sobre nosotros es dos veces más intensa. Es el mismo error de la psicofísica, que pensaba conducir a la cuantificación de nuestras afecciones y reacciones, mientras que todas pertenecen a la sola conciencia y no podrían ser comparables las unas con respecto a las otras.

Olvidemos estas claras divergencias, pues Bergson (1963) no dejó de escribir:

Una sensación solo podría estar en el nervio si el nervio sintiese, ahora bien, evidentemente el nervio no siente. Tomemos pues la sensación desde el punto donde el sentido común la localiza, saquémosla de ahí, acerquémosla al cerebro del que parece depender más aún que del nervio; y se llegaría así, lógicamente, por radicarla en el cerebro. Pero rápidamente nos damos cuenta que si no está en el punto en el que parece producirse, no podrá tampoco estar en otra parte; que, si no está en el nervio, tampoco estará en el cerebro. (p. 256)

O también, otra fórmula de la misma naturaleza y tan incisiva:

¿En qué consiste, por otra parte, la función del sistema cerebral? La excitación periférica, en lugar de propagarse directamente a la célula motriz de la médula, sube primero al encéfalo, luego desciende a las mismas células motrices de la médula que intervenían en el movimiento reflejo. ¿Qué ha ganado pues, en este rodeo y qué ha ido a buscar en las células llamadas sensitivas de la corteza cerebral? No comprendo, no comprenderé jamás que reciba ahí el milagroso poder de transformarse en representación de las cosas, y por lo demás considero inútil esta hipótesis, como se verá dentro de poco. Pero lo que yo veo muy bien es que estas células de las diversas regiones llamadas esenciales de la corteza, permiten a la excitación recibida ganar a voluntad tal o cual mecanismo motor de la médula espinal y escoger así su efecto. (Bergson, 1963, p. 228)

Nos es ofrecida una sola salida: los órganos sensoriales especializados recogen informaciones y mensajes. Los codifican o los traducen con el fin de que puedan ser transmitidos a los centros de la memoria que obedecen a los mismos principios comunicacionales (de naturaleza proteínica); estos últimos los reciben y los orientan allá donde se encuentran sus equivalentes.

De ahí se sigue que el espíritu, lo que se llama tal (tomar en cuenta la situación, su comprehensión, así como la actitud que podría convenir), se localiza tanto en la periferia como en el cerebro. Pero el error de las teorías neurológicas proviene de considerar solamente el polo central. Como han sacrificado o abandonado el otro extremo de este bucle (retroactivo), no pueden concebir el funcionamiento del conjunto, aunque la embriología y la histología no hayan 
dejado de recordar la equivalencia tisular y, por tanto, operacional del órgano sensorial y de la neurona cerebral. El propio Bergson (1963) ha insistido ya en ello en Materia y memoria:

Es suficiente con comparar la estructura del cerebro y la de la médula para convencerse que existe solamente una diferencia de complicación y no una diferencia de naturaleza entre las funciones del cerebro y la actividad refleja del sistema medular. (p. 228)

El solo cerebralismo conduce a un callejón sin salida: no puede dar cuenta del intercambio (interfacial) entre el mundo y nosotros. Lo cutáneo, o más bien los órganos receptores sensibles, son despreciados (mientras que la exteriología que deseamos construir ve en ellos los centinelas encargados de nuestra vitalidad) aunque solo sea porque son implantados afuera y porque la profundidad (el adentro) siempre se impone a la superficie que se cree desprotegida, de menor importancia, y, por tanto, que se la puede sacrificar. Nietzsche, Valéry e incluso Gide lo han subrayado, para solo citar algunos. En este sentido, menciona Gide (1925): "El que cava se hunde y el que se hunde se enceguece. La verdad es la apariencia; el misterio es la forma y lo que más profundo tiene el hombre es la piel" (p. 328). Pero el fisiólogo ha cedido probablemente ante el prejuicio; por consiguiente, ya no logra alojar el espíritu ("¿espíritu, dónde estás?". iY se interroga ansiosamente tanto más porque no puede responder!). A falta de disponerlo desde el comienzo(puesto que estamos en lo infrarreflexógeno y no recibimos de lo no directo, sino de las significaciones), ya no lo vuelve a encontrar. Al mismo tiempo acepta romper la corporeidad, ya no a la manera de los antiguos, sino como Cabanis y Bichat que la diferenciaban más de lo que la hendían (comenzaba por lo que es común a los vegetales y a los animales, después venía lo que solo es propio del animal y finalmente lo que particulariza al hombre, como la mutación que va a erguir el esqueleto, verticalizar el fémur y quitarle la función prensil al pie para concederle todo a la mano liberadora). Desde entonces, la dualidad opondrá una especie de envoltura secundaria que se cree defensiva (mientras que toda la sensibilidad se ha concentrado allí) a un santuario que es el único que decide. Volvemos a decir de paso que la medicina y la psiquiatría pagarán caro una tal fractura dentro de un cuerpo roto que, sin embargo, nos abre al mundo y nos previene.

Segunda conclusión: mantenemos nuestra oposición a la fórmula canónica reproducida por todas partes, "ver es ya juzgar". Es verdad que intervenimos para ver mejor lo que vemos. Nuestros recuerdos nos ayudan y el pasado viene a infiltrar el presente con el fin de permitirle anunciar mejor el porvenir (esto es lo que se producirá si decides aproximarte o alejarte de lo que has remarcado). Pero se termina rápidamente por descuidar lo que, en la base, convoca al "complemento"; el psicólogo no duda en ir más lejos y considerar la impresión 
como un material despreciable, un conjunto en migajas y amorfo, por no decir vacío. Debemos entonces reunir y ordenar ese desorden, ese polvo de elementos. Además, tampoco sabemos que, a fuerza de ver, llegamos a no ver nada (o a ya no oír). Según nosotros, esto debería reforzar la importancia de una primera mirada que no ha sido embotada por el hábito o la repetición. Pero esta evidencia del desgaste conduce al psicólogo a una conclusión bien diferente, la de una receptividad que se erosiona rápido y se anula por sí misma.

No cambiamos nuestras perspectivas ni lo que ellas implican; hemos reconocido la importancia y la ayuda de un cuerpo capaz, por sus captores, de recoger "el sentido": él lo hace posible y lo instituye (el sentido se define por lo demás con respecto a él, ¿qué "sentido" concederle en caso contrario?). Y nos informa principalmente de lo que nos espera. Ahora bien, este cruzamiento del mundo y de lo corporal nos da la clave de lo que nos asegura, nos aclara y nos salva.

El espíritu reside aquí gracias a la diferenciación de un cutáneo que se puede intercambiar con el cerebro, al mismo tiempo que este se vuelve sobre aquél, con sus luces, para ampliarlo y concluirlo. ¿Y por qué un tal montaje?

Porque la vida piensa continuarse (ella es lo inextirpable, aunque tenga que prevenirse del peligro y escaparle). Más tarde, el puro pensamiento no dejará de surgir y de corregir las graves insuficiencias del percibir. Se trata de una revolución que afectará incluso la sensorialidad y la ruptura epistemológica de base. Pero la vitalidad ganará aún este nuevo régimen.

En suma, no hesitamos colocar la vida y su perduración en la raíz de la conceptualización. Esta última ha logradocontornear la materia (una primera negación), llamada a disiparse (la entropía), pero el pensamiento vendrá luego (la segunda negación) a infiltrarse en ella para liberarla de sus carencias y de sus fracasos.

La técnica se comprende como lo que va a desbordar y a anular, en el límite, lo "percibido": debemos liberarnos de este medio que no depende de nosotros; por lo tanto, no podemos siempre contar con él ni atenernos a él. El hombre deberá inventar lo que lo autonomizará.

Tomemos una muestra que prestamos, como se debe, de Gaston Bachelard. Nos recuerda que nuestro universo, al comienzo, nos provee diversas "sustancias combustibles" que quemamos tanto para calentarnos como para iluminarnos (la bujía especialmente para este último uso). Pero la lámpara de Edison rompe con esta especie de práctica limitada, concretiza lo inverso de lo que la ha precedido y emplea un filamento incandescente, pero indestructible, esto es, una "técnica de no combustión". Además, este hilo está encerrado en una cápsula de vidrio en la que reina el vacío (mientras que el aire, o mejor el oxígeno, era necesario para 
alimentar la llama de la bujía o de la lámpara). Esta neoluz se integra a todo un sistema: supone la central eléctrica, es decir, una energía que se transmite y que viene de la conversión de la potencia mecánica. En resumen, instituimos otro mundo que difiere del que vivimos al comienzo, pero también continuamos evolucionando en nuestro medio inicial donde la sensación juega un papel irremplazable.

Tercera conclusión general: debemos notar que esta sensación que hemos festejado se cuida de copiar el mundo o de reproducirlo, pues el universo exterior y el cuerpo no se desjuntan. Por consiguiente, el sentir toma parte de estos dos, por lo que experimentamos que equivale al esbozo de una reacción (subjetiva) más que a un estímulo puramente físico (en esto hemos insistido que se trata de un "aviso").

La percepción mide nuestra acción posible sobre las cosas y por ello, inversamente la acción posible de las cosas sobre nosotros. Cuanto mayor es el poder de obrar del cuerpo, más amplio es el campo que abarca la percepción. La distancia que separa nuestro cuerpo de un objeto percibido mide, pues, verdaderamente la mayor o menor inminencia de un peligro, la mayor o menor proximidad del vencimiento de una promesa. (Bergson, 1963, p. 253)

Por ello, el hombre no ha cesado, en el curso de la evolución, de debilitar lo "rinencefálico" debido al exceso de proximidad (una distancia de otro estilo funcionará) entre el sujeto y el objeto.

Pero se critica sin dificultad la sensación cuando se la examina en términos de conocimiento, como si se tratase de un simple principio o como si reflejara solamente lo que nos bordea. Ahora bien, esta no lo restituye tal cual, sino que nos propone algo mejor: al informarnos sobre lo que nos conviene añade las huellas de luz que nos entrega los lineamientos de nuestra conducta más apropiada.

Pero con frecuencia el filósofo está deseoso de disminuirla. Sin embargo, su cuestionamiento no es inocente: tiende a despreciar la sensorialidad (y también la corporalidad) para solo glorificar mejor lo "mental" y también el "ascetismo", sin ni siquiera darse cuenta de que la sensación pertenece a lo espiritual (el espíritu está ya en ella y ella lo comparte con el cerebro del que no se separa, puesto que él es el otro extremo del bipolo que asegura nuestra conducta como nuestro gobierno).

Creemos llegar a una triple aserción:

1. La crítica del cerebralismo demasiado exclusivo y disociativo. Hemos opuesto el reconocimiento de la simbiosis "cerebro y piel" (captor). 
2. El sentir no se reduce a un juicio, incluso si la memoria se añade a él y lo completa.

3. La sensación no nos entrega un "reflejo" de lo real, sino más bien el efecto de nuestra presencia en este mundo y el anuncio de lo que nos ocurrirá (por tanto, la acción posible y la respuesta a un espectáculo sensible).

\section{Capítulo II. La desviación filosófica}

La exteriología - mejor aún, la exología - que deseamos construir y que nos ha permitido concebir de otra manera la sensación, rehabilitada y situada al mismo rango que el cerebro del que no se separa, se traduce por un cierto número de proposiciones:

1. Ante todo, el afuera no es completamente lo que se imagina: designa, en nuestra construcción, la interfaz entre el mundo y nosotros. Allí recibimos y reaccionamos a su mensaje con los dos movimientos: el centrípeto y el centrífugo. Es verdad que no dudamos en agrandar este dominio para incluir en él lo que fabricamos: los objetos, frutos de nuestra ingeniosidad, destinados a servirnos. Estos objetos-prótesis resultan de una especie de delegación: el psiquismo los ha confeccionado con el fin de que respondan mejor a nuestros usos. No cesamos de ordenarlos y de renovarlos, lo que les quita su peso de inmovilidad (la inercia) y de un "en sí" invariable. Una de las tareas del filósofo podría consistir en sacar de la sombra "la historia evolutiva de estos instrumentos", así como la habilidad composicional que ha presidido su génesis.

Los antropólogos lo han subrayado suficientemente: la verdadera diferencia entre el hombre y el animal se encuentra aquí al ser la herramienta su primera manifestación. Bergson lo ha notado en su Evolución creadora: el animal sigue estando prisionero para siempre de su "subjetividad" en el sentido de que solo pide a sus articulaciones, miembros, trompa o mandíbulas (a su cuerpo), los medios de defenderse o simplemente de actuar. No podría desdoblarse, concebir o incluso entrever una mano o un puño más fuerte que su propia mano, susceptible de reemplazarla y sobre todo de superarla. No le falta potencia, pero solo puede contar con la única estrategia que le impone su propia constitución, y esta no cambiará. En desquite, la herramienta nos saca de nuestra prisión debido a su independencia; se desprende de nosotros o más bien nos hemos transpuesto en ella. Esto significa la victoria de un "interior" que ha sabido "exteriorizarse"; podrá evolucionar y transformarse del todo al todo, de ahí el impulso técnico. Pronto la máquina-herramienta sustituirá la herramienta, puesto que esta permanece aún ligada a la energía muscular y a la prensión manual. También conviene conectarla a la potencia del fuego o a la violencia 
del vapor; marchamos hacia una motorización que está dispuesta a romper los últimos lazos que aún nos encadenan a la naturalidad.

2. Pero no por esto el adentro está negado, olvidado o sacrificado, sino que interviene ante todo para rematar las operaciones precedentes; sobre todo mostraremos que este nace de la sedimentación en nosotros de un "afuera" generativo. La interioridad cosecha lo que la exterioridad le ha legado de alguna manera.

Por ejemplo, los recuerdos son registrados después de ser seleccionados, pues solo conservamos lo esencial; la caja craneana los encierra y, sin duda, también los revisa. Según una fórmula conocida, un anciano que muere se parece a una biblioteca que arde. Pero a partir del momento en que es preciso almacenar demasiadas cosas y sustraer a la destrucción lo que se ha seleccionado, el cerebro va a renunciar a su función y a remitirla a una institución y a los lugares de la memoria y de preservación como el centro de documentación o el museo. Acabamos de presenciar un doble intercambio entre el adentro y el afuera (el afuera le confía al adentro lo que este a su vez, sobrecargado, transferirá a un afuera especializado y con mejores prestaciones). De esto resulta también una doble consecuencia: perdemos poco a poco la facultad de recordar porque renunciamos a nuestro trabajo de retención y nos contentamos con no perder el "lugar" donde hemos depositado la huella del pasado, confiando todo a las mega máquinas de recolección. Además, estas instituciones tienen tanto de subjetivo como de objetivo porque no se trata de acumular o de apilar con ellas, sino de organizar multitud de datos. El orden presidirá los emplazamientos, se evitará la confusión y también deberíamos reencontrarnos aquí sin dificultad. Finalmente, la biblioteca representa para nosotros un "cerebro colectivo", así como el triunfo del "espíritu objetivo", un espíritu que ha sabido exteriorizarse renunciando a un archivador limitado (lo cerebral).

3. Regresa permanentemente la pregunta lancinante: ¿dónde alojaremos "el pensamiento" del que ya no discernimos suficientemente su lugar ni su papel en el juego "exterior-interior"? ¿No se encuentra él dentro de nosotros?

Importa abandonar nuestros prejuicios más inveterados. El pensamiento solo nace verdaderamente a partir del momento en que abandona, para una mayor eficacia, las acciones comunes. El sentir solo vale como una intelección tan indiscutible como limitada porque está ligado a nuestras necesidades. Pero debemos rebasarlo cuando tropecemos con dificultades materiales y objetivas que nos desconciertan. El mundo se va a encargar de desconcertarnos. La reflexión se eleva con la ciencia, la técnica, el arte, todas llamadas a reconducir este universo o a reemplazarlo por el que precisamente construimos. 
De acá se sigue que el pensamiento se encuentra esencialmente en la terminación de nuestros dedos, en nuestros montajes y nuestros diversos dispositivos. De ninguna manera se encuentran en nosotros ni en el fondo de nuestra interioridad. Y si allí se aloja, es solo después de haber sido elaborado afuera, en presencia de obstáculos con los cuales nos topamos. El filósofo está demasiado inclinado a buscar en el solo entendimiento (por tanto, en sí mismo) las categorías que lo guiarían y lo iluminarían.

No podríamos estar a favor de la construcción sistemática de una "tabla de categorías". Incluso se ha llegado a deducir las unas de las otras a tal punto que el espíritu se descubre capaz de autoconstituirse y producir lo que lo define. En la Crítica de la razón pura, Kant (1978) establece, en efecto:

la lista de todos los conceptos originariamente puros de la síntesis contenidos a priori en el entendimiento, debido a los cuales este es, a su vez, simple entendimiento puro. Efectivamente, solo a través de ellos es capaz de entender algo de lo vario de la intuición, es decir, de pensar un objeto de esta última. (p. 114)

Kant prevé cuatro rúbricas distintas; cada una comprende tres de estos instrumentos a priori. La lógica más elemental no conoce y no privilegia más que la dualidad (el sí y el no), la dicotomía. ¿Por qué entonces la trilogía? Porque la tercera categoría resulta siempre de la unión de la segunda con la primera. De esta forma, la totalidad no es otra cosa que la pluralidad aliada con la unidad. En efecto (primera rúbrica, la cantidad), partimos de la unidad; después pasamos a su negación y oposición, esto es, la pluralidad. La síntesis que va a permitir fundir "lo que es afirmado" y lo que lo niega produce precisamente la totalidad (o la unidad de la pluralidad). Para cada grupo se asiste a esta misma construcción (o deducción).

¿Pero quién creería que podremos satisfacernos con un encuadre tan vago, de nociones tan flojas, cuando queremos llevar hasta el fondo problemas frecuentemente espinosos?

En su análisis, Kant no nos precisa el origen de las categorías que él recuenta y ordena las unas con respecto a las otras, excepto que él parece admitir una espontaneidad creadora del entendimiento. El filósofo temía sobre todo que estas categorías salieran de la experiencia. En este caso perderían su verdadera significación y su valor mismo (la racionalidad, la universalidad, la necesidad). Estaríamos condenados a lo circunstancial y a la suerte de lo que nos ocurra, en otros términos, a lo contingente, de donde se seguiría un escepticismo general que implicaría el fin del todo saber apodíctico.

Los conceptos no nos vienen de algo "sensible" impuesto o sugerido. Pero no por ello lo real deja de participar, por una parte, en su génesis. En este 
sentido, lo sensible plantea problemas y nos empuja, por consiguiente, a tener que inventar una salida. No podemos aceptar el desorden (es decir, datos a menudo contradictorios); el creador debe encontrar un camino que nos saque del callejón sin salida. La simple técnica nos ha enseñado ya que debemos revisar y diversificar nuestras herramientas intelectuales, nuestros esquemas y procedimientos. El acoplamiento idea-experiencia se impone; gracias a él lo real será reconocido en su complejidad y su abundancia. El espíritu, por su lado, se enriquecerá rectificándose o renovándose. Gaston Bachelard (1978) lo ha aclarado suficientemente: "Al poner sistemáticamente en dialéctica de cooperación a la razón y el objeto científico, nos aseguraremos lo mejor de los caracteres racionales del materialismo técnico y, viceversa, de los caracteres reales del racionalismo aplicado" (p. 16).

Los solos hechos —a pesar de su aspecto inconciliable y antinómico- no sabrían reclamar una respuesta: ¿No es necesario recurrir, entonces, a una jurisdicción competente, a la reflexión misma que zanjará? ¿No es un regreso al juicio (lo subjetivo) fundador? Pero, para nosotros, percibir asegura el papel mediador: nos sitia, nos reporta una especie de grieta por la cual el universo pierde su solidez (el ora blanco ora negro). La propia vida está en peligro; de acá sacamos el pensamiento que debe llegar hasta el fondo de lo que entraba nuestra existencia. Seguramente los hechos no imponen la urgencia de una solución o de una aclaración. Pero entre ellos y lo que los va a explicar, anulando su enfrentamiento o su cacofonía, se interpone el cuerpo que no tolera el callejón sin salida ni la confusión.

En suma, en y por su construcción, Kant solo tiene en cuenta lo real (lo determinado) y el pensamiento (lo determinante). Y con el fin de evitar el primero, carga con todo su peso al segundo. Creemos poder modificar esta filosofía que se desequilibra a partir del reconocimiento de un tercer término que nos evita regresar al primero y nos obliga a girarnos igualmente hacia el segundo.

Para nosotros, el artista mismo pertenece a la cohorte de los pensadores que participan en la victoria (sensorial) del sosiego. Por ejemplo, un artista plástico como Jacques de Villeglé se encuentra en un universo abigarrado, puesto que los muros de su ciudad están cubiertos de afiches que condicionan a los que los ven. Sin embargo, tales cuadros no pueden sino chocar porque lo publicitario recurre a escenas o eslóganes complacientes, por no decir atrayentes (la vivacidad de los tintes, la estética de la presentación, el juego de palabras, etc.). Esto es lo inaceptable: un tipo de arte es puesto al servicio de la trampa de favorecer la engañifa, la compra y el consumo. Rompamos pronto este falso acuerdo, esta talentosa superchería. El artista dilacera, entonces, los afiches (la arrancadura, la desgarradura) y, con los pedazos arrancados y coloreados, recompone 
un cuadro lleno de tumultos, pero liberado de toda utilización. Cambia lo que nos rodea y, con la ayuda de los restos, nos ofrece un conjunto que da vueltas y revueltas: la danza de las letras y de las líneas (han desaparecido las palabras enteras o las figuras completas). Estamos fascinados por esta libre fantasmagoría. El malestar sensorial se rebasa porque se ha llegado a robar sus constituyentes a la escena corrompida, así como a sus consignas.

¿No se precisaba un artista para realizar este espectáculo maravilloso? ¿No regresamos a la obligación de una consciencia que se rebela? Pero, por una parte, semejante innovación se ha operado en muchas escuelas o en lugares sin vínculo entre ellos. Estas invenciones rara vez están aisladas, aunque son simultáneas, lo que atestigua su inevitabilidad (esto disminuye la parte de lo personal, a tal punto el problema incita o presiona). Además, el acrecentamiento de la guerra comercial y la multiplicación de las vallas publicitarias contribuyen a esta réplica artística.

Persuadiremos con dificultad al filósofo, pues ha estado tan marcado por las lecciones y los principios de la tradición de Platón, Descartes y Kant. ¿Podrá aceptar la idea de que el pensamiento funciona afuera y que solo después se interioriza como recuerdo y saber, que son sus propias victorias? Para captarlo en su verdad primera conviene examinar este pensamiento a través de los problemas reales que ha debido resolver.

El error fundamental del cartesianismo, que habría de invadir y envenenar las teorías del conocimiento, ha consistido en "insularizar" el pensamiento, absolutizarlo y separarlo de sus operaciones (la efectividad), para fabricar "un pensamiento que cree pensarse a sí mismo" o que dialoga consigo mismo. La aplicación es mal vista o, más bien, es vista como un riesgo de fracaso. El sujeto se imagina que posee en sí mismo, en su trasfondo, los instrumentos del saber y, por consiguiente, los fundamentos de la realidad. Por ello, la creencia del metafísico, según la cual "el mundo es y solo es nuestra representación", la descubrimos en nosotros. En este sentido, "el conocer al ser la consecuencia es bueno" o también, en el mismo estilo, es suficiente con pensar claramente para conocer el exterior.

Ya Nietzsche se había resistido: vio en esta concepción imperialista del sujeto (la que exalta el cogito, el yo pienso o el simple pensamiento) un efecto del lenguaje o, más exactamente, de la gramaticalidad que comanda la construcción de todo enunciado. Desde que nos expresamos, estamos obligados, a hacer correr nuestra reflexión por un molde que entraña la descomposición, linealiza y, por tanto, separa lo que parecía indisociable: por un lado, dice la acción; por otro lado, indica su autor. Asimismo, y se trata de la misma deformación obligada, aísla 
el verbo al que desprende de sus complementos: todo es quebrado y vamos a pagar su precio por la creación de entidades ficticias, fetichizadas.

En el pasado hemos comentado esta frase trivial, aparentemente inocente:: "El viento sopla alrededor de la casa". Practicamos acá el fraccionamiento que acabamos de mencionar. Y ¿Qué es, en efecto, el viento por fuera del soplo? ¿En qué difiere el sujeto del enunciado, de su verbo? Pero, distanciando al uno del otro, se fabrica una potencia imaginaria (el viento) y terminamos por admitir la existencia de un viento que podría no soplar (soplará eventualmente más tarde). Sin duda, se ha levantado; antes de manifestarse permanecía inactivo, inmóvil en el horizonte (Eolo). Cuando sale de su estado - de reserva o apatía - precisa un motivo que explique su desencadenamiento; llegamos así a la cólera de esta fuerza sombría (la divinidad vengativa). Tememos esta fuerza y nos entregamos a prácticas mágicas con el fin de evitar el castigo o al menos el furor de esta divinidad. El responsable de esta deriva (el miedo del niño) se sitúa claramente en la gramática y su rotura ineluctable, lo que aísla un seudosustantivo dispuesto antes de la operación, y da nacimiento a una pura "entidad".

Además, cuando el viento sopla, lo hace por todas partes sin estar limitado a un lugar. Pero el relato — siempre engañador-indica solamente el lugar donde habito ("alrededor de la casa" a la que envuelve). Esto amplifica el miedo porque es a mí o a nosotros a los que el dios amenaza y apunta. Sin duda, le hemos fallado (la falta).

Notemos que el metafísico es extraviado por el mismo proceso: él también engendra puras abstracciones. Para ofrecer otra muestra, transforma el verbo (auxiliar) en un sustantivo. Por este hecho, emerge "el ser" —un infinitivo que se lo ha convertido en un sujeto o en un nombre- que exhibe su independencia ontológica, mientras que nosotros solo estamos rodeados por "realidades particulares" (¿las llamaremos "siendo"?) ...

El pensamiento (el cogito), en todo caso, no puede comprenderse por fuera del objeto o de la situación que asume (por eso la necesidad de un cogitatum). Es imposible desprender el entendimiento de lo que lo solicita. Nietzsche (1965) insistirá aquí: "En otro tiempo se creía en el "alma» como se creía en la gramática" (p. 493). También afirma:

Hay aún adeptos de la introspección bastante ingenuos como para creer que existen "certidumbres inmediatas", por ejemplo, el "yo pienso", o, como lo que fue la superstición de Schopenhauer, el "yo quiero». Como si el conocimiento consiguiese percibir su objeto pura y simplemente, bajo forma de "cosa en sí», como si no hubiese falsificación ni del lado del sujeto ni del lado del objeto... Sería pues preciso escapar a la mágica falacia de las palabras... El filósofo en cambio debe decirse: «Si yo descompongo el proceso lógico expresado en la frase 'yo pienso', obtengo una 
serie de afirmaciones arriesgadas, cuyo fundamento es difícil, quizás imposible de establecern. (Nietzsche, 1965, p. 469)

¿Qué podría ser este "pensar" por fuera de aquello en lo que piensa? Las dos cosas son la misma (el exterior y el interior consecutivo). Pero, como lo hemos mencionado, estamos obligados a separar la una de la otra, incluso si la frase se dedica a continuación, por medio de los artículos de conjugación y de los acuerdos entre las palabras, a volver a atar lo que ella ha dislocado. La fractura ha tenido lugar: nos produce un "pensamiento" de ahora en adelante santuarizado que juega a la autonomía y que, en un segundo tiempo, podrá ejercerse y dedicarse a una dificultad.

Pero según nosotros el pensamiento no toma su vuelo. Solo existe verdaderamente y se activa en presencia de un enigma o de una contradicción; nos parece que debemos dar una ilustración, por lo demás conocida, pero que nos permitirá captar el pensamiento in vivo.

A los químicos se les ha presentado una dificultad aparentemente mínima, pero irritante: dos sales, la una de ácido tártrico y la otra de su homólogo, el ácido paratártrico, coinciden químicamente y reaccionan de la misma manera. El análisis revela en ellos los mismos componentes y en las mismas proporciones; poseen, tanto el uno como el otro, las mismas propiedades, excepto una: uno de los dos no desvía el rayo de la luz polarizada. Este es un verdadero rompecabezas.

¿Cómo lo mismo puede ser lo otro? ¿Será menester creer en el dimorfismo o no se ganaría invalidando el resultado polarimétrico (la desviación)? La respuesta habitual, inspirada en la comodidad, consiste en ahogar el problema y considerarlo superfluo. Pero los hechos se resisten y no se prestan a la anulación. ¿Son verdaderos o falsos idénticos? Notemos, además, que se pondrá en funcionamiento otra astucia: los químicos se interrogan sobre los ácidos generadores de estas sales, el uno se llama ácido tártrico y el otro se llama ácido paratártrico. Este equivaldría a aquél, pero ligeramente mancillado; a esto se debe la diferencia. Esta explicación no se sostendrá y la pregunta subsiste: ¿cómo concebir y admitir la entera similitud y la no superposición?

Se sabe cuál ha sido la verdadera respuesta a este problema que toca la estructura molecular y cuya importancia nadie puede negar. Por lo demás, las nociones de isomería, mesomería e, incluso, de tautomería, salieron de acá y han renovado la física de los cuerpos, así como la cuestión de su configuración. Sería una manera hábil de debilitar el problema, así como su solución, si solo se viera acá una cuestión puntual y limitada, un caso embrollado que hay que desentrañar. Pero será necesario constituir una especie de nuevo estatuto ontológico que vaya más allá de la mecánica molecular o los juegos 
reaccionales de los elementos. Importa poder poner de acuerdo "lo mismo" y su opuesto. ¿Cómo?

Como se sabe, Pasteur tomó en cuenta "la disimetría de sentido inverso", la disposición de los átomos en la molécula o las orientaciones espaciales con el fin de explicar el divorcio entre los efectos de lo uno y de lo otro, uno que desvía y el otro que permanece inactivo. Correlativamente, mostraba que el inactivo en cuestión (el paratártrico) asocia en sí las dos formas, la derecha y la izquierda. Es un falso neutro puesto que incluye los dos contrarios. Mencionemos que Pasteur completó rápidamente la serie, puesto que aisló cuatro sustancias a la vez idénticas y, sin embargo, desfasadas las unas con respecto a las otras: el isómero derecho - la forma más frecuente-, el isómero izquierdo, el racémico (el derecho mezclado con el izquierdo en proporciones iguales) y, finalmente, un simétrico llamado "el destorcido", ni derecho ni izquierdo, que es el inactivo real. De acá se desprende sobre todo la noción de una "orientación espacial" que permite concebir la no coincidencia de los idénticos.

No seguiremos a Kant (1957) cuando escribe en los Prolegómenos: "No podemos hacer comprender la diferencia de cosas semejantes e iguales y sin embargo no coincidentes - por ejemplo, de las volutas inversamente enrolladas- por ningún concepto sino únicamente con respecto a la mano derecha y a la mano izquierda" (p. 49). La sola espacialidad o su ocupación no permite entrar en la comprensión de las estructuras, sino que creemos que el científico ha ido más lejos y nos ayuda a captar la razón de la diferencia (de acá la estereoquímica).

Pero retendremos de este recuerdo que el científico ha podido desentrañar el embrollo. El pensamiento está llamado a poner orden en los resultados rebeldes, discordantes y diseminados. Si lo colocamos por fuera de estos, seguro de sí mismo, inmóvil, caerá pronto en lo tautológico (el A que se refleja en A, o el sujeto que se considera a sí mismo objeto de su propia actividad). Descartemos la creencia de un pensamiento puro para conservar solo un pensamiento de esto o de aquello, o incluso un pensamiento que piensa esto o lo de más allá. No cometamos el error de un pensamiento esquizofrenizante, que nace de la hendidura entre el acto y sus efectos, puesto que los dos no pueden ser concebidos separadamente. No podríamos eximirnos de mediación; la exterioridad se revela indispensable para la constitución del llamado pensamiento que, en gran medida, ella lo condiciona.

El análisis de Descartes, que se quiere demostrativo, a favor del solo cogito (el puro pensamiento) no nos parece riguroso.

En los Principios de filosofía —el parágrafo 9 se titula "Lo que es pensar" —, Descartes anota de entrada: 
Por la palabra pensar entiendo todo lo que se hace en nosotros de tal suerte que lo apercibimos inmediatamente por medio de nosotros mismos; por este motivo no solamente comprender, querer, imaginar, sino también sentir, es la misma cosa que pensar.

¿No se infla aquí la noción a tal punto que pierde su contenido o sus contornos? En el mismo parágrafo, Descartes se entrega a una extraña experiencia pero que es susceptible de definir el puro pensamiento (el cogito). En efecto admite: "Puede ocurrir que piense ver o caminar, aunque no abra los ojos y no me mueva de mi sitio, pues esto me ocurre algunas veces mientras duermo. Y lo mismo podría quizás ocurrirme, aunque no tuviese cuerpo". En los dos casos, el filósofo reconoce que se beneficia del

me parece que veo o que camino. Esta conclusión es tan absolutamente verdadera que no puedo dudar de ella, a causa de que se refiere al alma que es la única que tiene la facultad de sentir, o bien de pensar de cualquier otra manera que sea. (Descartes, § 9)

Ya sea que sueñe - veo entonces sin abrir los ojos - o que alucine - veo, pero mi cuerpo ha desaparecido-, el pensamiento no deja de subsistir; fácilmente podríamos aprehenderlo.

Además, estamos sorprendidos por la equivalencia entre el "sentir" y el "pensar". Y no entendemos claramente por qué "este pensamiento o este sentimiento" no resultarían de una ilusión. Es verdad que se trata de una ilusión, pero continuamos pensando (el pensamiento de una ilusión, a tal punto no podemos desligar lo uno de lo otro).

Asimismo, Descartes -el partidario de un puro cogito que se piensa a sí mismo- se interroga sobre lo que está fundamentalmente en él y que nadie podría quitarle (lo no enucleable). ¿Va a reconocer aquí en él y para él la facultad de moverse o de caminar? Pero, como no excluye que pueda estar privado de un cuerpo, no podría contar con actividades que implican la presencia de este cuerpo para definirse. Entonces solo le queda el pensamiento, pues no puede desprenderse de él, en tal punto duplica el "yo soy, yo existo". La desaparición de esta existencia entrañaría, en efecto, lo que ella implica: el pensamiento. Por tanto, según Descartes "soy claramente una cosa que piensa" (o mejor que se piensa a sí misma). Si el propio Dios viene a engañarlo es porque él existe, pues él no puede ser engañado si no existe.

En suma, la palabra pensamiento - la filosofía idealista y absolutizada del cogito- cambia de significación: o Descartes cuenta con el "me parece" (incluso si no camino me parece que camino y ya esto es suficiente) o con la equivalencia implícita entre el "yo pienso" y el "yo soy, yo existo". También es posible que Descartes haya recurrido a lo que nadie puede abolir en mí sin suprimir mi propia 
presencia. Así, es preciso que yo exista claramente para poder ser manipulado por una astucia. Esta pluralidad de respuestas o de argumentos nos conduce a sostener, con Nietzsche (1965), que "el pensamiento no puede aprehenderse de manera directa, en un estado puro y desnudo".

El que, apoyado en una especie de intuición del conocimiento, se aventura a responder inmediatamente a esta cuestión de metafísica, como hace el que dice: "yo pienso y sé que por lo menos esto es verdadero, real, cierto", este provocará hoy en el filósofo una sonrisa y dos preguntas: «Caballero-le dirá quizás el filósofo-parece inverosímil que no os podáis equivocar, mas, ¿por qué queréis la verdad a cualquier precio?». (Nietzsche, 1965, p. 469)

Por lo demás, lo único que discutimos es el final de la cita pues. El filósofo, lejos de sonreír como lo imagina Nietzsche, se encarga más bien de sostener y saludar esta ontología: el pensamiento autonomizado y asegurado en sí mismo. Además, ¿por qué el filósofo no buscaría lo verdadero?

A nuestros ojos, para agravar el error metafísico de Descartes, el filósofo prosigue su deslizamiento (la sumisión a la gramática y la descomposición que ella autoriza) y procede a un nuevo recorte para imponer "el yo" al pensamiento que piensa o se piensa (el cogito). Desde el momento en que recurre a una actividad y retiene un verbo (el yo pienso), le es preciso acompañarlo de la sombra de un sujeto (el yo). En este sentido, el yo es reivindicado y colorea la operación al mismo tiempo que es espaciado de ella. Esta separación es sustancializada a pesar del lazo que la gramática trata de restaurar por las "concordancias" y otras combinaciones.

¿Pero es el yo el que piensa? ¿El pensamiento que orientamos hacia lo objetivo (el cogitatum indispensable) es atraído hacia su contrario, esto es, el lado subjetivo? Por ello, solicitamos a Nietzsche (1884) su violencia protestataria:

Seamos más prudentes que Descartes que ha permanecido preso en la trampa de las palabras. Cogito, a decir verdad, no es más que una sola palabra pero su sentido es múltiple [...] Este célebre cogito implica que $1^{\circ}$ alguna cosa piensa, $2^{\circ} \mathrm{y}$ yo creo que soy el que pienso, $3^{\circ}$ pero admitiendo incluso que este segundo punto sea incierto, al ser materia de creencia, el primer punto "alguna cosa piensa" contienen igualmente una creencia, la de que Pensar sea una actividad a la cual es menester imaginar un sujeto, así solo sea ese "alguna cosa"; y el ergo sum no significa sino eso. (p. 23, citado por Wotling, 1999, pp. 31-32)

¿Tengo necesidad, después de una verificación en la que sostengo que $7+$ 5 = 12 (una adición bien modesta), de anotar que soy "yo" el que realizó esta operación? Este añadido parecerá no solamente inútil, sino también engañador, porque la exactitud del resultado viene precisamente de que no importa quién debe llegar a la misma suma. Descartemos lo superfluo; más vale afirmar, como en otra parte, que "ello piensa, es denkt, cogitatur". 
Por lo demás, ¿puedo convocar a mi antojo los pensamientos? Schopenhauer anota: "Los pensamientos no vienen cuando lo queremos sino cuando ellos lo quieren". Es verdad que algunos han creído poder justificar esta referencia al "yo", puesto que nosotros mismos nos oponemos, por lo demás, a las separaciones. ¿Por qué alejar al agente, al responsable? ¿Por qué no mencionarlo a la manera de una signatura en la parte baja de un texto escrito? ¿No ganaría el pensamiento si se nombrara al que lo ha iniciado y precisado? Perdería su impersonalidad, así como su austeridad. La ley y la teoría física llevan claramente, una y otra, la referencia a su autor: la ley de Gay-Lussac, la ley de Ohm, la teoría darwiniana, etc. Pero no por ello el resultado final se particulariza; solo se lo ha hecho más vivo porque evoca la audacia del que lo ha revelado.

No compartimos estas observaciones. Si la ley científica se interesa a veces en designar al científico que la ha impuesto, esta se limita a indicarlo sin que el patronímico entre en el enunciado propiamente dicho. Por otro lado, el "yo" del cogito está incluido en él e, ipso facto, lo subjetiviza y, por lo mismo, disminuye su alcance. "Por lo demás, ¿es verdaderamente el yo el que piensa?". Nietzsche (1965), el iconoclasta, escribe una anotación temeraria al respecto:

Es difícil, por no decir imposible de establecer; por ejemplo, que soy yo el que pienso, que debe haber en general una cosa que piensa, que "pensar» es la actividad y el efecto de un ser considerado como causa, que existe un "yo»; en fin, que ya ha sido establecido lo que hay que entender por pensar, es decir, que yo sé lo que quiere decir pensar. (p. 469)

A fin de cuentas, el cartesianismo no nos lleva a rectificar o a modificar nuestra tesis filosófica resueltamente exológica; rechazamos la existencia de un pensamiento que lograría pensarse a sí mismo. ¿ Qué otro contenido habría para él? Tampoco aceptamos el "yo" que se le pega, tanto más porque se pretende universal y la repartición para todos de la verdad. Incluso el "nosotros" colectivo nos parecería aún un abuso y continuaría dividiendo. Preconizamos la fructuosa complementariedad del sujeto y del objeto (indisociables), mientras que el lenguaje insinúa en nosotros sus efectos malhechores. De esta manera, disocia el sujeto (el agente), el verbo (el actuar) y el resultado operacional. Cada uno de estos momentos, desde que se los escinde, desarrolla en nosotros lo ficticio. El yo se asegura de ocupar toda la plaza. ¿Pero qué puede ser un pensamiento preocupado solamente en su reverberación? Permanezcamos en nuestras fórmulas iniciales: el objeto obliga a pensar y el pensamiento mismo se reconoce en los objetos que construye.

Si la filosofía francesa ha sido influida por el modo de andar cartesiano, también ha sido marcada - en su vertiente empírica o antropológica- por los análisis de Maine de Biran que habría de resucitar el arsenal "reflexivo" e intensificar la atracción por la interioridad (el yo íntimo del que el Journal nos 
relata hasta las más ínfimas preocupaciones como una especie de entrevista de él consigo mismo). También el afuera saldrá de esto desacreditado y desterrado, mientras que el adentro será privilegiado más que nunca.

Es claro que Maine de Biran debía combatir desde el comienzo el sensacionismo de Condillac. En este sentido, rechaza concederle un papel a la sola impresión porque valoriza, por el contrario, lo que nosotros acá añadimos: la indispensable espontaneidad. Podría ser incluso que Maine de Biran haya deformado a Condillac con el fin de poner el acento, por un movimiento de balanceo, en el otro extremo de la actividad perceptiva debilitando el lado receptivo y aumentando el aporte del sujeto.

En efecto, para que Condillac definiera las facultades mentales y comprendiera las principales operaciones a las cuales el individuo se entrega en una especie de autogénesis, creyó que tenía que comenzar con una simple estatua que se pone a "sentir un olor de rosa". Por una parte, decide atenerse al órgano más desprovisto y el que menos informa: "Creímos deber comenzar con el olfato porque de todos los sentidos es el que parece contribuir menos al conocimiento del espíritu humano" (Condillac, 1798b, p. 50); así se explica Condillac sobre su famosa tentativa. Por otra parte, piensa que puede sacar todo el psiquismo de este ejercicio elemental (abrirse al olor de una rosa).

El juicio, la reflexión, los deseos, las pasiones, etc. no son sino la sensación que se transforma de modo diferente. Pero, se dirá, los animales tienen sentidos y sin embargo su alma no es capaz de las mismas facultades que la del hombre. Esto es verdad y la lectura de esta obra [el Tratado de las sensaciones] hará sensible su razón. (Condillac, 1798b, pp. 50-51)

Se conoce su explicación: los animales no se benefician de órganos sensoriales tan desarrollados como los nuestros. Solo el tacto asegura la diferencia.

La ficción condillaciana (la estatua) significa que el filósofo espera, por medio de su odisea psíquica, descender al grado cero, a la ausencia de todo previo y a la tabula rasa. Pero cada uno ve el peligro que corre: no podrá engendrar "el yo" con la ayuda de la sensación más empobrecida (el olfato), y los sucesores — con Maine de Biran a la cabeza- no dejarán de sacar ventaja y aumentar la potencia del "yo"; de esta manera, restablecen el equilibrio roto. El debate que anima la psicología nos parece falso: dado que los primeros teóricos no han conservado la bipolaridad que hemos expuesto -el exterior y el interior inseparables y complementarios- entran en querellas sin fin; o bien el exterior tiende a imponerse sin lograrlo (ha sido demasiado disminuido) o bien el interior regresa fuertemente. Pero nos encierra en la prisión de una subjetividad aislada, por no decir exangüe. 
Por lo demás, no excluimos que Maine de Biran haya deformado un poco la iniciativa de Condillac (1798b):

Imaginamos una estatua organizada interiormente como nosotros, y animada de un espíritu privado de todo tipo de ideas. Supusimos además que el exterior todo de mármol no le permitía el uso de ninguna de sus sentidos, y nos reservamos la libertad de abrirlos a nuestro gusto. (p. 49)

A decir verdad, esta metáfora de la estatua induce rápidamente a error a Maine de Biran: la toma al pie de la letra (sin embargo, Condillac la considera dotada de animación). Se apresura pronto, en este sentido, a anular los aportes de esta Galatea (la estatua de Pigmalión a la cual Venus le dio la vida):

Mientras que la estatua se identifica con su modificación actual, con un olor de rosa por ejemplo, como no hay de ninguna manera existencia individual ni tampoco yo, y como el sujeto que conoce o que tiene -hipotéticamente- la facultad de conocer no se distingue de ninguna forma de la cosa o del objeto que se conoce, no se puede reconocer en este primer punto de partida [...] el hecho del conocimiento. (De Biran, 1932, pp. 15-16)

Maine de Biran (1932) añade aquí en una nota:

Sentir o tener una sensación no es la misma cosa que percibir o sentir la sensación; lo primero expresa un hecho exterior [...] la segunda fórmula expresa un hecho completamente interior en el que el individuo que siente y percibe es a la vez testigo y actor. (p. 16)

Por tanto, este solo exterior no podría ser un "hecho primitivo" con el cual se construiría el "yo" indispensable en el origen. Toda la obra de Maine de Biran tratará de rebajar lo sensitivo.

Por lo demás ¿cómo una estatua, incluso bien dispuesta, podría sentir "el olor de la rosa que se le aproxima"? La primera vez que ella la respira no podría cualificarla; le sería preciso recurrir a sus recuerdos (la memoria) e incluso a una elaboración intelectual que aísla esta flor (es claramente una rosa, no la confundo con otra flor). Maine de Biran saca sin dificultad de acá la conclusión de una consciencia soberana y directamente participante.

El filósofo recuerda también que las sensaciones o las impresiones - las de los olores, sabores, incluso colores, todas vagas lo más a menudo y afectivas, mezcladas al placer o al disgusto- nos absorben y, por consiguiente, no las referimos fácilmente a un "objeto exterior". ¿Hasta qué punto, entonces, estamos, al comienzo, inmersos en la subjetividad donde Condillac cree poder desengancharnos? De esta manera, Maine de Biran nos muestra la importancia de la interioridad (lo objetivo es tardío y es el yo el que, poco a poco, lo determina; es pues el punto de vista opuesto al que Condillac creía elaborar). Maine de Biran 
va a desplegar ante nuestros ojos los poderes de la interioridad constitutiva y a reducir a casi nada lo que encierra el estímulo físico o la sensación que recibimos (su sentido). Anteriormente hemos sostenido que no podemos separar lo "receptivo" y lo "cerebral", puesto que viven el uno del otro o el uno por el otro. Pero aquí, por el contrario, asistimos a la absorción del uno por el otro y a la glorificación del uno que termina por suprimir el otro. De ahí resulta la fisura entre el afuera (y lo que tiene que ver con él) y el adentro, que es lo único que cuenta.

Primera batalla o primer argumento: Maine de Biran corta en dos la sensorialidad. En este sentido, le da su parte al fuego: uno de los grupos saldrá casi eliminado porque el sujeto no puede asumirlo y, por tanto, lo abandona. Por otro lado, el segundo grupo se beneficia de un psiquismo que lo fundamenta y lo enriquece. Debemos contar con dos tipos de sensibilidad: de acá se sigue que la repetición anula rápidamente la primera. De esta manera, el que habita cerca de un molino ruidoso termina por no escucharlo (la costumbre), mientras que la misma repetición exalta la segunda. Por ello, gracias al ejercicio, la percepción se vuelve más distinta, incluso si a veces es necesario temer el peso de la rutina.

Si estoy expuesto durante mucho tiempo al mismo grado de temperatura, si siento frecuentemente el mismo olor, el mismo sabor, terminaré por no sentir nada del todo, y aunque la causa subsista siempre afuera ella será, para mí, como si no existiera. (De Biran, 1841, p. 74)

Convendría, sin duda, distinguir dentro de esta clase esas afecciones que marchan por sí mismas a su borradura: "las percepciones sordas, confusas, imposibles de localizar" (y la memoria de Maine de Biran sobre las percepciones oscuras prueba que no las ha ignorado). Estas últimas definen el grado más bajo de una organicidad ciega.

Del conjunto que acabamos de evocar, desprendamos rápidamente los "estados" que precisamente el hábito despierta, en lugar de disminuirlos. Maine de Biran llega hasta deplorar que un mismo término —el de sensación- sirva para designar a los unos y a los otros, mientras que todo los aleja:

Si nos servimos del mismo término sensación para expresar, ora una simple modificación afectiva, ora un producto compuesto de una impresión, de un movimiento, de una operación, etc., ¿no habrá que temer que la identidad de expresión nos lleve a confundir frecuentemente cosas por completo diferentes y que solo sirva para confirmar ilusiones a las cuales estamos ya bastante inclinados? (De Biran, 1841, pp. 20-21)

En este último caso el sentir no consiste en padecer, sino en recibir lo que nos concedemos gracias a la energía que gastamos. El yo trabaja primero en producir, después en recolectar lo que ha provocado. Por ejemplo, si el tacto se limita a un contacto, solo nos informa medianamente. Pero desde que nos movemos 
y exploramos lo real, tomamos conciencia de algunas pequeñas resistencias: la eventual rugosidad (o de la lisura), las finas asperezas, en resumen, un campo por fin diferenciado. Por lo demás, por esto conviene añadir a los cinco sentidos tradicionales un sexto, así como lo pedía Destutt. Este hace de coeficiente y anima todos los otros, es decir, la motilidad; nuestro propio ojo solo puede ver a través de sus propios movimientos.

Cuando me muevo, mi ser se extiende afuera, pero todo el tiempo presente a sí mismo. Se reencuentra, se capta [...] Cada movimiento, cada paso que da, es una modificación muy distinta que me afecta doblemente tanto por sí misma, como por el acto que la determina; soy yo el que mueve, o que quiere mover, y es además el yo el que es movido. (De Biran, 1841, p. 23)

De la misma forma, si realizo un gesto o si me desplazo de un lugar a otro, creo de cierta manera la impresión que experimento.

Finalmente, la fuerza de este análisis biraniano viene de una completa inversión: la sensación, que en principio nos abre al mundo exterior, con este filósofo se vuelve lo que el "yo" se concede a sí mismo. La tesis de "la interioridad pura" nunca ha conocido semejante fiesta, puesto que el yo o la autoconstitución se impone allí donde este siempre se había visto en una situación de pasividad (el que recibe o es informado).

Por lo demás Maine de Biran (1932) reconoce que mete sus pasos en las huellas de Descartes:

Recojo —escribe él一 el principio de Descartes: «Yo Pienso, yo existo» y, descendiendo en mí mismo, busco caracterizar más expresamente cuál es este pensamiento primitivo, sustancial, que está llamado a constituir toda mi existencia individual, y la encuentro identificada en su fuente con el sentimiento de una acción o de un esfuerzo querido. Este esfuerzo será pues para mí el hecho primitivo. (p. 177)

Lo más notable es que Maine de Biran acompaña su punto de vista con numerosas consideraciones médicas o fisiológicas interesantes: por ejemplo —como lo sostiene su tesis-, le reconoce al elefante una especie de inteligencia que lo distingue de los otros animales, porque a pesar de su peso y de su lentitud para desplazarse, su trompa se muestra con tantas actuaciones y tan móvil como la mano del hombre. Maine de Biran puede escalonar, entonces, los animales según el número y la finura de sus órganos motores.

El filósofo recuerda numerosas experiencias intentadas por los unos y los otros, susceptibles de reforzar sus conclusiones. Buffon, por ejemplo, en una Memoria sobre los colores artificiales, señala que si el ojo se fija sobre un color termina rápidamente por no verlo más (la extinción del afuera). Pero en presencia de una mezcla de azul y de verde, dado que ha sido acaparado antes por 
el azul, este ojo no distingue ya el verde. En resumen, la sensación, cuando no intervenimos, pierde su consistencia, por lo que no merece servir de pilar de la psicología y mucho menos de la autogénesis de la personalidad.

Segundo argumento y segunda batalla. El filósofo no se limita a despreciar la pura impresión en provecho de una sensación que solo existe a través de nuestra participación (en marcha hacia la autoconstitución de un yo soberano). Antes bien, multiplica los análisis, incluso los más radicales, que confirman la extenuación de la "receptividad".

En efecto, solo escuchamos si hablamos y porque hablamos; los sonidos solo nos llegan si sabemos articularlos y retomarlos, así como lo prueba el sordomudo. Aquí, el oído recoge lo que producimos, así como la voz emite lo que nos ofrecemos y recibimos. No se puede imaginar un circuito más cerrado. Las dos funciones, o más bien los órganos, permanecen separadas; en estas condiciones, la actividad no corre ningún riesgo de ser confundida o absorbida por la "pasividad".

Es imposible ir más lejos puesto que somos a la vez la causa y el efecto, la producción y la recepción. Nos modificamos sin la intervención de un factor extraño. Tal es acá el punto fuerte de la teoría: tomamos todo a nuestra cuenta y el bucle se cierra sobre sí mismo. ¿Pero si alguien distinto de mí mismo me habla, no tengo que escucharlo? Es menester, sin embargo, acompañar esta palabra que deseo escuchar; debo murmurarla interiormente y replicarla. Escuchar se convierte en hablarse a sí mismo. Solo nos recibimos a nosotros mismos y esta autoefectuación no conoce límites. Antes bien, va a dar cuenta de nuestros pensamientos más complejos: "El oído y la voz están siempre en acción en nuestras operaciones intelectuales más secretas, que son como discursos que nos dirigimos bajito a nosotros mismos pues es necesario siempre que escuchemos nuestras ideas para concebirlas" (De Biran, 1932, p. 497).

Tercer argumento y tercera batalla. Se trata siempre de ir lo más lejos posible en lo que disminuye la impresión (la guerra librada contra la exterioridad). Precisamente, la simple palabra que designa la cosa va a permitir anular "lo que recibimos", esto es, lo sensorial mismo. En efecto, el lenguaje goza de un poder incomparable: gracias a él, la "cosa" que indica se vuelve o permanece presente mientras que está ausente. Ayer dependíamos de los objetos (por lo demás débilmente, si se sigue a Maine de Biran, puesto que solo contaban en la medida en que los invistiéramos e incluso los imitáramos). De aquí en adelante, dueños de los signos, nos hemos deshecho de ellos. Nos volvemos los amos de nuestros recuerdos, así como de nuestros pensamientos. Repitiendo aún la palabra, descubrimos cada vez al "yo" que se hace presente a sí mismo. 
En esta óptica, Maine de Biran no duda en retomar por su cuenta la concepción de los Ideólogos y especialmente la de Lavoisier (para este científico, una ciencia solo es una lengua bien hecha). En este sentido, Maine de Biran (1841) escribe:

La lengua de la química moderna es bien propia para servirnos de ejemplo; retenemos sus términos con tanta facilidad que captamos las ideas; nunca los unos se aíslan de las otras y no se puede aprender ya la lengua sin la ciencia como tampoco la ciencia sin la lengua. (p. 240)

Maine de Biran añade acá una lluvia de ventajas: la claridad, la rapidez, la precisión, e, incluso, las articulaciones halagüeñas para la oreja facilitan tanto la evocación como la pronunciación. Finalmente, esta etiqueta dice a menudo más de lo que ella designa. Por otra parte, ella implica "la voz". En este sentido, confirma nuestro poder personal, lo que excluye la simple pasividad y supone nuestro concurso activo, esto es, el pensamiento.

Es verdad que un instrumento que ayuda tanto arriesga con perjudicarnos debido a su eficacia y de su autonomía. El filósofo teme que las palabras, que han permitido nuestra victoria sobre lo real (de acá en adelante expulsado), sustituya a tal punto eso real, que podrían encerrarnos en la temible prisión de una escolástica fantasmática sin vínculo con nuestro universo. Maine de Biran condena, por esta razón, "la lengua universal" que se desarrollaría sin preocuparse por lo que ella representa, esto es, el programa leibniziano de la combinatoria (una pasigrafía). En los escritos de Maine de Biran leemos, entonces, un llamado de atención contra las "trazas" o los equivalentes motores e icónicos. Si gracias a ellos hemos escapado a la tiranía de las cosas (presión e impresión), esta no es una razón para caer en lo opuesto, esto es, la entrada en lo imaginario. Debemos imperativamente permanecer en el interior del querer, que a su vez se ha emancipado de la sensibilidad.

Pero W. James habría de asestarle, sin embargo, un golpe a la teoría biraniana que, so pretexto de liberarnos, nos ha atrincherado en la subjetividad (y por el descenso de esta pendiente, el filósofo no dejará a continuación de entrar en lo inmaterial - un alma enteramente despojada de sus lazos con el cuerpo-y por ahí el descubrimiento de otra vida).

James debía descubrir en el movimiento voluntario (el sentimiento del esfuerzo) el temblor obligado de los músculos exteriores, así como numerosos acompañamientos corporales (una respiración jadeante, la glotis que se cierra, etc.). La acción que decidimos se localiza ante todo en la periferia y no en la sola y pura interioridad. 
No es posible cortar lo cerebral y lo muscular, el adentro y el afuera. El esfuerzo los reúne. Querer significa sobre todo comenzar y, por ello, para y con él, un lado centrípeto. En caso contrario, la decisión que creemos haber tomado no se inscribe e irá a perderse en la virtualidad o la sola eventualidad.

La obra de Maine de Biran nos ha parecido ejemplar: ha sacado el conjunto del psiquismo de un solo lado (la interiorización); pero la cuerda ha sido tan tensada que debía romperse. A su manera, esta filosofía recomienza, mutatis mutandis, el cartesianismo: el pensamiento encerrado sobre sí mismo cree poder reengendrar el mundo a partir de sí mismo; de ahí su soberanía. Maine de Biran también piensa reencontrar el absoluto "del sentido íntimo" con el sentimiento del esfuerzo, pero finalmente no pudo separarlo de la corporeidad ni de su presencia.

Más próximo de nosotros, el psicoanálisis habría de amplificar e intensificar lo que los metafísicos (Descartes) y los psicólogos (Maine de Biran) habían tratado de establecer: en lo más profundo de nosotros no se situaría "el yo", sino "un yo más abisal" que habría constituido el superyo, esto es, un "inconsciente" que equivale más a un hiperyo que a un hipoyo. En efecto, este me originaliza: el "yo" condensa la trivialidad y lo ordinario, mientras que el superyo designa las normas sociales a las cuales estamos sometidos. También el terapeuta deberá salir al descubrimiento de "esta alma oculta" (la psicología de las profundidades), puesto que esta dará cuenta tanto de nuestra conducta como de nuestros fracasos. Bajo cualquier hipótesis, instala en nosotros la dualidad o al menos una escisión que puede desorganizarnos.

Pero nosotros no tomaremos por ese camino. Para nosotros, el adentro o lo que se considera como tal se reconoce siempre afuera. $\mathrm{Y}$ el psicoanálisis, tal como lo comprendemos, no rompe esta perspectiva porque nos parece verdad que el "inconsciente" se lee y se descubre en plena visibilidad. Se "entrega" y se exhibe a nuestros ojos aun cuando no lo veamos. La anotación de Valéry no hace sino resonar: "Tratar de ver lo que es visible, y sobre todo de no ver lo que es invisible. Los filósofos expían con bastante frecuencia la falta de haberse dedicado a lo contrario".

¿No tiene el psicoanalista, en la cura, el papel de una pantalla en la que se proyectan las estructuras neuróticas, los fantasmas y los deseos (prohibidos)? Generalmente, en la vida ordinaria - el adentro colorea el desenvolvimiento de nuestras relaciones - la transferencia funciona, pero implica inmediatamente la respuesta de una contratransferencia, lo que enreda pronto y limita los intercambios. A la agresividad eventual, respondemos con la misma violencia y salida de la reprobación. Pero el analista -especie de virtuoso de su dispositivo "óptico" - ha aprendido "la neutralidad" sin importar lo que ocurra; 
por consiguiente, el enfermo despliega sobre él sus propias pulsiones. Ya nada obstaculiza este movimiento, puesto que el analista se dedica a recibir lo que el sujeto concentra en él. ¿Si, por ejemplo, el paciente no viene a la cita, llega retrasado, se comporta de manera desprendida, insólita o agresiva, no es el comienzo, la entrada en una escenografía indicadora? ¿Pero qué sucede si el analizado se encierra en el silencio y también en la más completa inmovilidad, si no dice ya nada y no se mueve? Se trata entonces de una sintomatología ruidosa y prometedora. Ya se resiste el sujeto y, por tanto, lucha contra fuerzas que no dejarán de manifestarse. Cederá entonces, puesto que comienza por construir barricadas y por defenderse. Además, el terapeuta también ha aprendido a pillarse los menores "tics", los gestos, las mímicas, todo lo que es lateral y mínimo que vigilamos mal y que no podemos contener. La censura se fija probablemente sobre lo que ella juzga "fundamental". Por ello, esta focalización filtra lo que considera secundario, pero que no por ello deja de ser revelador.

Por lo demás, Freud no ha dejado de darnos las claves gracias a las cuales interpretamos "la vida cotidiana": los olvidos, los lapsus, los gustos y las repulsiones, las exageraciones notorias, los juegos de fisonomía, las repeticiones estériles, etc. No existe nada que no nos "traicione" (a nuestros ojos no se trata de una especie de engaño puesto que el sujeto desea comunicar lo más íntimo que tiene). La sola manera como caminamos, nos articulamos (precipitada o confusamente, o pretenciosa o metódicamente) o nos vestimos es suficiente para "develarnos". Freud (1934) ha dado numerosos ejemplos de esto; mencionemos uno de los más anodinos:

E. Jones cuenta que, por razones que ignora, dejó una vez, durante varios días sobre su escritorio una carta que había escrito. Por fin se decidió a expedirla, pero le fue devuelta por la oficina de Correos pues había olvidado escribir la dirección. Habiendo reparado este olvido volvió a echar la carta al correo, pero esta vez olvidó poner las estampillas. Una tal repetición del acto fallido le obligó a confesarse que en el fondo no quería mandar la carta mencionad. (Freud, 1934, p. 65)

Los olvidos o los actos fallidos, entre un rosario de otros, alegan a favor de un inconsciente que nosotros consideramos periférico o claramente superficial.

El Rorschach, por su lado, nos confirma la extrema difusión de lo que creíamos conservar en nosotros: es suficiente con que se disponga ante nosotros un conjunto no estructurado (en el límite, como se sabe, manchas de tinta; pero sería mejor, con el fin de limitar la artificialidad, colocar en un rincón de una pieza con poca luz un conjunto de cosas heteróclitas inciertas y desorganizadas) para que, inmediatamente, si no conocemos la astucia, percibamos lo que tememos o lo que esperamos. En resumen, desde que la pura exterioridad se reduce o incluso se anula, terminamos por "exponernos nosotros mismos"; le damos a los otros la posibilidad de vernos. La ausencia de un contenido que nos bloquearía y se 
impondría descomprime sin dificultad un yo que se propaga. No solamente nos preocuparemos entonces del "contenido" (lo que el espectador ha observado o creído reconocer), sino también, más ampliamente, conviene tener en cuenta "la manera" como es leído este afuera. ¿El sujeto retiene el conjunto o los detalles? ¿Y cuáles detalles? Se distinguen los internos y los periféricos. En principio, los segundos son más importantes para la evaluación porque van en el sentido de la "desconcentración" y, por tanto, de una liberación con respecto a una unidad demasiado defensiva y coloreada de narcisismo. Pero si "el todo" se impone, juzgamos, grosso modo, este síntoma como positivo. Sin embargo, lo mejor consiste en ligar "este conjunto" a las particularidades que lo singularizan, lo que indica una mirada que no está demasiado desprendida y que muerde lo real. Imaginamos que un esquizofrénico aislará elementos puntuales eventualmente ridículos y de los más mínimos. Desintegrado él mismo, desconoce la unidad del cuadro que se le ha presentado. De esta manera, captamos tanto las aptitudes como las deficiencias a través de la apercepción externa en la descripción de lo que nos ha sido mostrado. En resumen, en lo que vemos nos damos a ver; el afuera dice a su manera el adentro.

Los analistas de la psiquis han puesto a punto muchos otros procedimientos destinados a facilitar la relajación del yo y, por tanto, favorables a su visibilidad: el sujeto no puede defenderse de las trampas que se le han tendido y que incluso no sospecha. Jung ha utilizado la siguiente estratagema: pronuncia una palabra ordinaria cualquiera y le pide a quien acaba de escucharla que reaccione inmediatamente con asociaciones libres. ¿Qué es lo que el signo verbal desata en él? Por ejemplo, si digo agua podrá venir enseguida: vaso, fuente, sed, lavadero, etc. Un cronómetro permite, al mismo tiempo, medir "el tiempo de respuesta" (y sobre todo el de la "latencia" o del retardo). En efecto, si en esta palabra inductora afluyen recuerdos embarazosos, evoca situaciones prohibidas o incluso emociones antiguas, pierde su "indiferenciación" o su neutralidad que facilitaba los automatismos y la rapidez serial. Las secuencias que tardan en llegar son suficientes para detectar la molestia, e incluso la nebulosa sensible, que el observador busca precisar.

Desea llegar a "una escena subyacente" que abriga el psiquismo de quien se interroga. El pasado o el traumatismo entrabando la fluidez de la respuesta indicarían "la fijación".

En esta misma perspectiva debemos también reconocer la importancia de algunos análisis de Reich que constituyen la biopsiquiatría que él ha fundado, aunque ella se haya perdido en consideraciones insostenibles, por no decir delirantes. Este psiquiatra no ha dejado de tomar en serio la idea de que el enfermo no deja de expresarse abierta y corporalmente (en las antípodas de lo 
oculto o de lo abisal). Reich desconfía de los decires del enfermo porque ellos le sirven de "mecanismo de defensa"; su habilidad de hablar le permite llenar el vacío y desviar la atención, que sería preciso ponerle a la complicación gestual (el manierismo), a las rigideces o a las zonas inmovilizadas o retraídas. De esta manera, nada sería más revelador que una perturbación de la respiración (se vuelve superficial, inspiramos mal como si nos defendiéramos de lo que entra en nosotros, lo que significa la alteridad que nos amenaza y que nos gana). Por lo demás, los antiguos localizaban en el diafragma las afecciones del alma (phrène designa en griego el músculo que separa el corazón y los pulmones de las vísceras inferiores, pero también la sede de los sentimientos y de las pasiones, en fin, de la inteligencia misma. De acá proviene nuestra palabra frenesí. El sufijo phrène se reencuentra en los vocablos psiquiátricos como oligofrenia y esquizofrenia. Sin duda, los griegos habían remarcado la fragilidad de lo respiratorio. Los Latinos retomaron esta tesis puesto que su spiritus remite tanto al soplo como al alma).

El cuerpo, del que no podría separarse el alma, no puede dejar de exhibir, a su manera, sus malestares o la inadaptación que lo golpea. No existe ningún síntoma psicopsiquiátrico que no se histerice, puesto que el trastorno vivido implica siempre una demanda comunitaria. Por tanto, se dirige a los que nos rodean (sea que comporten una acusación o sea que reclamen una ayuda). El paciente reacciona con crispaciones, reticencia o con reserva; necesariamente debemos destacar, en tal o cual lugar sensible, una especie de fractura y su rigidez subsecuente. "Una actitud positiva y generosa frente a la vida solo es posible si el organismo se comporta como una unidad, si las emociones correspondientes circulan libremente en los órganos y tejidos" (Reich, 1971, p. 324). Y Reich debía enseñarnos a examinar cuidadosamente las diversas regiones corporales tocadas electivamente por la neurosis: el anillo ocular, después el oral, el torácico, el diafragmático (por no decir respiratorio), el abdominal, etc. Todos ellos son segmentos naturalmente llevados a significar (al yo indirectamente). En cada nivel observamos sin dificultad "una contractura" a tal punto que la salud va de la mano de la flexibilidad, la variedad y la movilidad. Por ejemplo, según Reich (1971): "Las expresiones afectivas que corresponden al deseo de llorar, de morder, de vociferar, de chupar, de gemir son tributarias de la libre movilidad del segmento ocular" (p. 313).

Se adivina cómo el terapeuta buscará, en un primer momento, romper las "resistencias" y obligar al neurótico a favorecer la circulación en el conjunto de su cuerpo que escapará ipso facto a la escisión.

Recordemos que esta psiquiatría somatopsíquica se cuida mucho de intentar una exploración de lo inaccesible y de la mitología de la profundidad o 
de la interioridad, a la que recusa con vigor. Se atiene a la musculatura; ella es excelente para mostrar las marcas de la crispación que exponen el psiquismo. A él le parece necesario "tocar" al paciente y escrutar su cuerpo. El psicoanalista clásico permanece demasiado encerrado en la palabra, los fantasmas, lo que implica, con respecto al paciente, la distancia o el alejamiento.

En todo caso no podríamos aceptar la arquitectura freudiana: el yo, el superyo, el inconsciente (o el ello). ¿Cómo admitir que este último se alojaría en el fondo de nuestros actos y que podría incluso inspirar, mientras que su realidad se presta a tantas dudas? Estamos de acuerdo con Sartre (1981) que ve en él el solo "hecho de conocer lo que no se quiere conocer". Para que la censura reprima tan eficazmente, es preciso (sin riesgo de equivocarse puesto que sabemos de su vigilancia) que haya descubierto lo "prohibido" y lo que ella debe impedir. Se sigue, entonces, la identificación del inconsciente: tiene que ver más con una sobreconciencia que con la ignorancia o con lo desconocido; solamente fingimos ignorarlo mientras que nos obsesiona y nos está perpetuamente presente (ique no se filtre y que no atraviese la defensa!).

Sartre (1981) relata, en El ser y la nada, situaciones donde funciona esta ambivalencia: lo ignoro, es decir, que "lo sé para no saberlo", tal como aquella muchacha que mantiene una relación amorosa, busca prolongarla, termina incluso por ceder su mano al que la seduce y que acepta lo que, sin embargo, rechaza.

Abandonar la mano es consentir por sí misma al flirt, es comprometerse; retirarla es romper la armonía turbia e inestable que constituye el encanto de esa hora. Sabido es lo que se produce entonces: la joven abandona su mano, pero no percibe que la abandona. No lo percibe porque, casualmente, ella es en ese instante puro espíritu [...] Y entre tanto, se ha cumplido el divorcio del cuerpo y del alma: la mano reposa inerte entre las manos cálidas de su pareja, ni consentidora ni resistente: una cosa. (Sartre, 1981, p. 101)

Esta mujer se ha refugiado en la trascendencia y se ha transformado también en un objeto (la facticidad) en un desdoblamiento radical y operacional. Una hendidura así organizada tiene que ver con una astucia (la duplicidad, la mala fe). Ante nuestros ojos, a través de esta escena, Sartre nos muestra el trabajo del inconsciente hace sus preparativos a través de la construcción de un sujeto que obtiene satisfacciones a pesar de las prohibiciones que pesan sobre él.

Rematemos nuestra demostración: si es verdad que el adentro no deja de manifestarse afuera (el inconsciente no está alojado en el fondo de nuestro ser, en una especie de noche), se expresa a plena luz. Pero, en el sentido contrario, el adentro nace de la interiorización de un afuera impregnante. Tampoco nos sorprende que este pueda, de alguna manera, volver a la superficie de donde viene. 
¿Qué encontramos, en efecto, en este aparente "adentro" que no sean los residuos de nuestro medio, nuestra educación, nuestros sueños y nuestras contradicciones mal resueltas? La sociedad familiar, la primera y la que más marca, solo vive de sordos enfrentamientos. Esta dinámica se imprime en nosotros. Los hijos se celan entre sí puesto que el uno le quita al otro el afecto que se reservaba: de aquí el drama de Caín que debía matar a su hermano Abel. Las niñas tampoco escapan a su inferiorización, aunque sueñen con ser metamorfoseadas en muchachos sin que haya necesidad de recurrir al fantasma de la escena de la castración (el complejo de Diana). Finalmente y sobre todo el niño, sometido a la triangulación edípica, no puede más que odiar a su padre en la medida en que él le roba a su madre (por esto también el incesto). Esta guerra intestina terminará sin duda por agotarse o extinguirse, pero se instalará en los recuerdos y forjará nuestra arqueología neurótica.

Gracias al conocimiento de esta trayectoria, cuasi inevitable, el psicoanálisis logrará sacar de la oscuridad lo que nos paralizaba o continuaba subyugándonos y engulléndonos. Pero, por una parte, este reinserta en la sociedad al que se alejaba de ella (salvándolo de su pasado lo reintegra), al mismo tiempo que, por otra parte, castiga su deseo que seguía una pendiente incestuosa. Por este hecho, firma tanto una victoria como una derrota; victoria porque el sujeto desdramatiza su existencia, liquida de alguna manera lo que lo invadía y regresa a conductas "normalizadas"; pero fracaso porque el beneficiario de esta cura no cuestiona, sino que por el contrario acepta lo que lo había asesinado. Se "mitridatiza" [se inmuniza acostumbrándose al veneno], se pliega a un medio patógeno. Pierde así lo que lo hacía original; se "uniformiza".

Concluimos que el adentro, dirigido por el afuera al que reproduce, está alineado sobre él. No discutimos la importancia de la comunidad familiar —la fructífera relación padre, madre, hijo ${ }^{6}$-, pero ella solo vale en la medida en que no se endurece y termina por autorizar libres intercambios. La verdadera educación, así como lo indica la palabra (educere, conducir al afuera), debe ayudarnos a abandonar la esfera que nos ha formado primero. Los otros grupos en los cuales entraremos deberían beneficiarse de nuestra salida del primero que nos acaparaba. En caso contrario, recomenzamos y corremos el riesgo de deslizarnos, por ejemplo, hacia el paternalismo. Por esto somos partidarios de una psicoterapia que nos acomode a nuestro pasado: si por un lado lo liquida, por el otro lo hace habitable; expulsa lo patológico residual, pero conserva el cuadro y sus valores latentes.

Correlativamente, no logramos considerar como "una tendencia fundamental" que nos empujaría a la autodestrucción (la pulsión de muerte). Interpretamos de

$6 \quad$ Remitimos a nuestro texto Une nouvelle morale : Famille, travail, nation (Dagognet, 1998). Nota del autor. 
otra manera tanto su presencia como su virulencia: vemos acá la consecuencia de una cultura (el afuera) que solo conoce la rivalidad, la avidez y la eliminación de los prójimos considerados como competidores o como adversarios. Esta guerra incesante, que reviste las formas más mezquinas (ipienso en estrangular al que abrazo!), termina por transmitirse a la psique. Antes que tener que soportar el odio y la violencia (que va a invertirse en autoagresión), ¿cómo no preferir la paz, el nirvana y la desaparición de sí mismo?

¿Es esta una anotación arbitraria? B. Malinowsky, etnólogo de Melanesia, evoca un mundo que no conoce estas vicisitudes: por una parte, la sexualidad se practica desde la tierna edad y no conoce la represión (o la censura); por otra parte, la opresión y sus complicaciones solo aparecen en el momento en que el matriarcado cede ante el patriarcado y cuando, paralelamente, las riquezas se acumulan y arrastran consigo la monogamia con el fin de evitar la dispersión de los bienes. En resumen, de manera casi experimental, el etnólogo discierne los comienzos de una economía del provecho y del intercambio, así como lo que rompe la primera comunidad, puesto que los unos (los propietarios) van a aplastar y a someter a los otros (los desposeídos). Pronto aparecerán los daños de la ascesis y los controles que pesarán sobre la libertad genital.

Bien sea que se trate de la familia o del medio social más amplio (el mundo de la producción que termina por comandar el de la reproducción), ellos repercuten sobre nosotros y nos condicionan. El afuera posee un tal poder de malignidad que envenena al sujeto, un sujeto que incorpora en sí lo que algunos no dejan de descubrir (luego) en él, en su fondo.

Debemos pues resolver aquí: a) el adentro solo se manifiesta afuera, incluso si no sabemos reconocerlo ahí (el inconsciente se oculta allí donde no pensamos desalojarlo). Fue Balzac el que con su Dime cómo caminas... nos inició en esta lectura. b) El afuera, por su lado, no deja de confundirlo todo, de ocupar y de impregnar el adentro. Sin embargo, la filosofía no ha tenido en cuenta la existencia de esta bipolaridad y se ha consagrado, más bien, a una concepción del sujeto separado y único soberano.

Los motivos que han pesado para ella, que presiden la dualidad (un adentro sin verdadera relación con un afuera que lo alienaría), varían, como lo hemos anotado en nuestro recorrido. Descartes se adhiere a esto porque no cuestiona el lenguaje y sus construcciones gramaticales que le obligan a distinguir el sujeto, el verbo y el complemento; de ahí la idea de una actividad pura e independiente (el pensar) desprendida de aquello a lo que se aplica (el complemento obligado). Por su parte, Maine de Biran, que busca examinar hasta el mínimo movimiento (el gesto), aísla la iniciativa que lo gatilla, de la participación muscular, que la escolta desde el comienzo. Cree que se puede desprender la intención -el 
querer (o el programa) - de su traducción somática, disociación que falsea sus conclusiones. Este filósofo, replegado sobre sí mismo, inseguro y dudando, se felicita entonces por haber encontrado en sí mismo un poder que trascendería los determinantes que lo acompañan. Finalmente, el psicoanálisis justifica ya el largor de la cura por la inercia y la resistencia de aquello que él cree que saca de la sombra: lo falsamente enterrado que, sin embargo, solo pide ser encontrado. $\mathrm{Al}$ alojarlo en lo inaccesible (en el fondo) aumenta su mérito: desenterrar lo que habría sido recubierto. Al mismo tiempo, el psicoanálisis se hace cómplice de la mistificación porque considera como "científico", médico o realista lo que tiene que ver con las secuelas del mundo capitalista, por sí mismo patógeno. Por no reconocerlo, fabrica "entidades pulsionales o instintuales" bastante gratuitas. Considerar como objetivo lo que resulta más o menos directamente de un conjunto económico-cultural conduce a tomar la sombra de lo real por lo real mismo, lo que significa el peor de los errores especulares.

Evitemos, sin embargo, un posible malentendido: no discutimos la existencia de un yo (el ego) particularmente activo, sino que ya lo hemos ligado a la sensorialidad que en sí misma es directamente informante. Tenemos una particular consideración con este bipolo, generalmente sacrificado en provecho de la sola mens (el solo pensamiento que se pensaría a sí mismo), a tal punto que ya no es comprensible el lazo entre "la impresión" desacreditada, considerada como un simple choque, y su entrada en una inteligencia que la recibe. Creemos poder asegurar la simbiosis entre este primer afuera - la corporeidad avisada y que nos avisa - y el adentro (la cerebralidad).

Pero el yo, tal como lo comprendemos, no se sitúa allí donde los antropólogos lo han implantado con frecuencia. En gran medida, si registra "mensajes" que los órganos sensoriales le dirigen, él se visualiza sobre todo afuera porque se dedica — como lo mostraremos ulteriormente- a modificar el mundo (la técnica, el arte, e incluso las prácticas religiosas). No acantonamos al ego en la sola receptividad, puesto que él va a disponer lo que lo tocará o lo rodeará.

Previamente a esta construcción, el yo no se reduce a la sensorialidad; nace también en la intersección de las comunidades a las cuales pertenece (la familiar, la profesional, la cultural, la social, muchos medios en los cuales está inmerso comprendido el de su domicilio y el de su vecindario).

¿Qué soy o dónde estoy, sino en la intersección de círculos que me rodean y que pueden oponerse entre ellos para obligar a decisiones inevitables? Por ello, concedemos valor a la sociometría, no solamente porque ha hecho congeniar abiertamente las viejas nociones de yo (moi) y de sí (soi) $)^{7}$ o porque en el mismo

Moreno (1954) afirma al respecto: "los conceptos de yo y de sí me parecen que son mediocres puntos de partida [...] Son conceptos vagos, incomprensibles, intangibles". 
movimiento define el individuo como enclavado por multiasociaciones, sino porque nos enseña también a evaluar la intensidad y el poder de estas diversas inclusiones. ¿Por qué, según ella, cada cual está obligado a una existencia interactiva, sino es porque solo ella revitaliza y estimula al sujeto? Por acá se confirma lo que los economistas han verificado, es decir, que el trabajo productivo supone la división de las tareas, pero sobre todo la reunión en el mismo taller de todos los obreros (solidarizados). Adam Smith, como Marx, ha insistido sobre este operador de la actuación industrial. Marx incluso va más lejos: si estos obreros son enganchados a ocupaciones distintas, sin relación los unos con los otros, su sola aproximación bajo un mismo techo es suficiente para que produzcan más. "El simple contacto social engendra una emulación... La razón de esto reside en que el hombre es, por naturaleza, sino un animal político, como entiende Aristóteles, por lo menos un animal social" (Marx, 1946, pp. 262-263).

Para medir las atracciones y las repulsiones de los unos con respecto a los otros, la sociometría recurre a hábiles estratagemas. Veamos una: pretendo que me es necesario fragmentar el conjunto o la banda, con miras a una o a otra operación, cualquiera que sea la razón dada que haga creíble la formación de grupos limitados. También se le va a solicitar a cada uno que escriba o al menos designe los nombres de aquellos con los cuales desearía estar asociado, por no preguntar los nombres de aquellos con los cuales se entiende mal. Incluso, si es posible, preguntaremos por quién puede ser seleccionado; se le concede valor a la "escogencia recíproca": uno es querido por otro que también lo desea. Tratamos de esta forma de fijar las líneas estructurantes o la red constitutiva de esta microsociedad. Seguramente, esta prueba tiene sus límites: si el interrogado tiene, por ejemplo, demasiado en cuenta la naturaleza de la tarea prevista (aunque irreal), puede alinear los nombres de los que juzga más competentes en este dominio con el fin de estar unido a ellos. En este sentido, no descubre los lazos afectivos y personales que la cartografía o el sociograma esperaba obtener.

De todo esto resultan para nosotros dos principios de base. 1) Los aislados corren riesgos. Tienden a intensificar su confinamiento, su "marginalidad". Se ha podido observar que los que son alejados o rechazados cometen muchos más accidentes de trabajo que los que son incorporados a un equipo. En resumen, marcharían directa o indirectamente, si no hacia la enfermedad mental, al menos hacia una grave inadaptación, premisas de la autoacusación y de la depresión. 2) Por el contrario, los privilegiados no cesan de extender sus contactos humanos. Soportan impunemente las sacudidas que agitan tarde que temprano a los conjuntos y gozan de una vigorosa salud. Emprenden y arrastran.

Debemos a los socioterapeutas una clara lección: la existencia misma de un individuo, lo que él cree "original" y personal, refleja la sorda organización 
en la cual está inserto y de la que depende. El yo, en tanto que tal, sustancialmente hablando, no existe; él resulta de su pertenencia a muchas comunidades. Asimismo, lo más interesante consistiría en analizar los conflictos y los desgarramientos posibles que nacen de su adhesión a estos sistemas que se combaten en él. Nuestra conclusión debería salir reforzada: el yo solo vive de la intersección de estas redes que expresan los vínculos tanto como las distancias de los individuos entre sí.

\section{Referencias}

Bachelard, G. (1978). El racionalismo aplicado. Paidós.

Bergson, H. (1962). Las dos fuentes de la moral y de la religión. Sudamericana.

Bergson, H. (1963). Materia y memoria \& Evolución creadora, in H. Bergson, Obras escogidas. Aguilar.

Berkeley, G. (1944). Tres diálogos entre Hylas y Philonous. En A. Leroy (trad.), Euvres choisies 2. Aubier.

Berkeley, G. (1968). Tratado sobre los principios del conocimiento humano. Losada.

Bichat, X. (1800) y Pichot, A. (1994). Recherches physiologiques sur la vie et la mort (première partie); Anatomie générale appliquée à la physiologie et à la médecine (préface, Considérations générales); Discours sur l'étude de la physiologie. Flammarion.

Cabanis, P. (1802). Rapports du physique et du moral de l'homme. Tome premier. L'imprimerie de Crapelet. https://bit.ly/2U105N2

Condillac, E. (1798a). Oeuvres de Condillac. Tome I. Revues, corrigées par l'auteur, imprimées sur ses manuscrits autographes, et augmentées de la "Langue des calculs", ouvrage posthume. Essai sur l'origine dés connaissances humaines. L'imprimerie de CH. Houel. https://bit.ly/2I1DIy7

Condillac, E. (1798b). Oeuvres de Condillac. Tome III, revues, corrigées par l'auteur, imprimées sur ses manuscrits autographes et augmentées de la Langue des calculs, ouvrage posthume. L'imprimerie de CH. Houel. https://gallica.bnf.fr/ark:/12148/bpt6k65555284/f5.item

Dagognet, F. (1975). Por una teoría general de las formas. Traducido por María Cecilia Gómez B. Medellín, Abril de 2002.

Dagognet, F. (1998). Une nouvelle morale : Famille, travail, nation. Les empêcheurs de Penser en Rond. Una Nueva moral: familia, trabajo, nación. Traducido por Luis Alfonso Paláu C., Medellín, 2009.

Dagognet, F. (2002). Changement de perspective: Le dedans et le dehors. La Table Ronde. Cambio de perspectiva: el adentro y el afuera. Traducido por Luis Alfonso Paláu C., Medellín, 2006.

De Biran, M. (1841). Oeuvres de Maine de Biran. Tome premier. Influence de l'habitude. Sur la faculté de penser. V. Cousin. https://bit.ly/315jhOO

De Biran, M. (1932). Oeuvres de Maine de Biran. Tome VIII-IX, Essai sur les fondements de la psychologie et sur ses rapports avec l'étude de la nature. Librairie Félix Alcan.

Descartes (1642). Meditación metafísica. Madrid: Alfaguara, 1977.

Diderot, D. (1749). Lettre sur les aveugles. En P. Vernière (ed.), E Euvres philosophiques. Garnier.

Freud, S. (1934). Introducción al psicoanálisis II. Teoría general de las neurosis. Biblioteca Nueva. 
Gide, A. (1925). Les faux-monnayeurs. Gallimard. https://archive.org/details/in.ernet.dli.2015.358301/ mode/2up

Jeannerod, M. (1992). Organisation et désorganisation des fonctions mentales: le syndrome frontal. Revue de Métaphysique et de Morale, 97(2), 235-253.

Kant, E. (1957). Prolégomènes à toute métaphysique future qui pourra se présenter comme Science. J. Vrin.

Kant. E. (1968). Crítica del juicio. Losada.

Kant, E. (1978). Crítica de la razón pura. Alfaguara.

Lecat, C. (1767). Euvres physiologiques. Vol II.

Leriche, R. (1940). Chirurgie de la douleur. Masson.

Marx, K. (1946). El capital. Crítica de la Economía Política. Tomo I, Volumen I. Libro I. El proceso de producción del capital. Fondo de Cultura Económica.

Merleau-Ponty, M. (2014). Le primat de la perception et ses conséquences philosophiques. Verdier.

Müller, J. (1840). Tratado de fisiología.

Moreno, J. L. (1954) Fundamentos de Sociometría. Editorial Paidos.

Nietzsche, F. (1965). Obras completas. Tomo III. Aguilar.

Pradines, M. (1943). Traité de psychologie genérale. T. I. Presses Universitaires de France.

Pradines, M. (1948). Traité de psychologie générale. T.2. Le génie humain. Parte 2, Ses instruments. Presses Universitaires de France.

Reich, W. (1971). L'Analyse caractérielle. Payot.

Sartre, J. P. (1981). El Ser y la Nada. Ensayo de ontología fenomenológica. Losada.

Valéry, P. (1957). Introducción al método de Leonardo da Vinci in Euvres. Gallimard.

Wotling, P. (1999). La pensée du sous-sol: statut et structure de la psychologie dans la philosophie de Nietzsche. Editions Allia. 